\title{
Influence of the Landscape Template on Chemical and Physical Habitat for Brown Trout Within a Boreal Stream Network
}

\author{
Ishi Buffam ${ }^{1 \star t}$, Kevin Bishop ${ }^{2}$ and Hjalmar Laudon ${ }^{1}$ \\ ${ }^{1}$ Department of Forest Ecology and Management, Swedish University of Agricultural Sciences, Umeå, Sweden, ${ }^{2}$ Department \\ of Aquatic Sciences and Assessment, Swedish University of Agricultural Sciences, Uppsala, Sweden
}

OPEN ACCESS

Edited by:

Núria Catalán,

United States Geological Survey (USGS), United States

Reviewed by:

Francisco J. Peñas,

Environmental Hydraulics Institute (IHCantabria), Spain

Douglas Burns,

United States Geological Survey (USGS), United States

${ }^{*}$ Correspondence: Ishi Buffam ishi.buffam@slu.se

tPresent address: Ishi Buffam,

Department of Landscape Architecture, Planning and Management, Swedish University of Agricultural Sciences, Alnarp, Sweden

Specialty section:

This article was submitted to Water and Critical Zone a section of the journal

Frontiers in Water

Received: 19 March 2021

Accepted: 16 August 2021 Published: 08 September 2021

Citation: Buffam I, Bishop K and Laudon $H$ (2021) Influence of the Landscape Template on Chemical and Physical Habitat for Brown Trout Within a Boreal Stream Network.

Front. Water 3:683070.

doi: 10.3389/frwa.2021.683070
We used the distribution of stream-dwelling brown trout (Salmo trutta) in a $67 \mathrm{~km}^{2}$ boreal catchment to explore the importance of environmental organizing factors at a range of spatial scales, including whole-catchment characteristics derived from map data, and stream reach chemical and physical characteristics. Brown trout were not observed at any sites characterized by $\mathrm{pH}<5.0$ during the spring snowmelt episode, matching published toxicity thresholds. Brown trout distributions were patchy even in less acidic regions of the stream network, positively associated with glaciofluvial substrate and negatively associated with fine sand/silty sediments. A multivariate model including only whole-catchment characteristics explained $43 \%$ of the variation in brown trout densities, while models with local site physical habitat characteristics or local stream chemistry explained 33 and 25\%, respectively. At the stream reach scale, physical habitat apparently played a primary role in organizing brown trout distributions in this stream network, with acidity placing an additional restriction by excluding brown trout from acidic headwater streams. Much of the strength of the catchment characteristics-fish association could be explained by the correlation of catchment-scale landscape characteristics with local stream chemistry and site physical characteristics. These results, consistent with the concept of multiple hierarchical environmental filters regulating the distribution of this fish species, underline the importance of considering a range of spatial scales and both physical and chemical environments when attempting to manage or restore streams for brown trout.

Keywords: pH, Salmo trutta, salmonid distributions, catchment-scale, Sweden

\section{INTRODUCTION}

In the decades since Hynes (1975) encouraged stream ecologists not to consider running waters in isolation, considerable research effort has been focused on understanding linkages between freshwaters and their watersheds. Until recently, understanding of the terrestrial-aquatic connection has relied primarily on small-scale studies, based on individual research plots, hillslopes and small catchments where detailed measurements can be made. Conversely, most questions about sustainability of water resources and protection of aquatic ecosystems concern the landscape or regional scale (Fausch et al., 2002). The effects on stream ecosystems due to land use practices such 
as forestry and agriculture have intensified in many areas, the impact of long-range transport of air pollutants is felt over very large regions, and climate change is a truly global issue. All of these perturbations affect surface water ecosystems over a range of spatial and temporal scales (Oliveira et al., 2012), and are mediated by interactions with the terrestrial landscape (Strayer et al., 2003; Townsend et al., 2003).

Stream fishes respond to different chemical, physical and biological drivers in their environment, over a range of spatial and temporal scales (Fausch et al., 2002; Kennard et al., 2007; Olden et al., 2010; Herlihy et al., 2020), resulting in complex distributional patterns in heterogeneous physical environments. Brown trout (Salmo trutta) for example, in spite of being the most common native salmonid in Scandinavian freshwaters and a successful invader in many North American freshwaters, has a distribution which is patchy at multiple spatial scales even within its potential range (Kocovsky and Carline, 2005; Öhlund et al., 2008; Alexiades and Fisher, 2015).

The limited distribution of brown trout has been attributed in some regions to the effects of either natural acidity or anthropogenic acidification, or a combination of the two (Hesthagen et al., 1999; Kocovsky and Carline, 2005). Because of its toxic effects, often exacerbated by high concentrations of inorganic aluminum $\left(\mathrm{Al}_{\mathrm{i}}\right)$, acidity can restrict the spatial distribution of many fish species including the moderately acidsensitive brown trout (Baker and Christensen, 1991; Hesthagen et al., 1999). A survey of streams in central Sweden in 1978 revealed clear $\mathrm{pH}$ thresholds for the presence of brown trout, while other habitat characteristics were not well correlated to trout distributions (Andersson and Andersson, 1984). Similarly, a survey of acid-impacted streams in southwest Norway found that in the late 1980s-early 1990s, acidity was the primary determinant of brown trout distribution (Hesthagen et al., 1999). In a review emphasizing Scandinavian streams, Degerman and Lingdell (1993) reported that viable brown trout populations are not found in streams which experienced minimum $\mathrm{pH}$ below $\mathrm{pH}$ $4.7-5.0$, and reproduction is adversely affected already in the $\mathrm{pH}$ 5.0-5.4 range. In watersheds in the northeast USA, brown trout were absent from stream sites with mean pH below 5.7 (Baldigo and Lawrence, 2001; Kocovsky and Carline, 2005).

In less acidic streams, brown trout distributions are often linked to variation in physical habitat (e.g., Alcaraz-Hernandez et al., 2016). Brown trout requirements vary with life stage, but are generally related to physical streambed substrate size, water temperature, water velocity, water depth, and physical cover (Mäki-Petäys et al., 1997; Armstrong et al., 2003; Dieterman and Hoxmeier, 2011; Alcaraz-Hernandez et al., 2016). Thus, even in areas with sites spanning the relevant acidity range, spatial distributions of individual fish species can be controlled by other environmental/ecological factors, like physical habitat, temperature, food source, competition, predation, or non-acidity related water quality parameters (e.g., Jutila et al., 1999; Jackson et al., 2001; Brazner et al., 2005). In surveys of watersheds in the northeastern USA, for instance, brown trout were absent from many high $\mathrm{pH}$ sites, and their absence at these sites was attributed to poor habitat or competition from brook trout (Baldigo and Lawrence, 2001; Kocovsky and Carline, 2005).
Both local chemical and physical habitat can be strongly influenced by the surrounding terrestrial landscape and catchment characteristics (Harpold et al., 2013). Stream physical habitat can be related to characteristics of the surrounding watershed (e.g., slope, soil type, landcover/land use) or in the near-stream zone (e.g., riparian vegetation, shading). In the Pacific northwest region of the United States for instance, geomorphology, and hydrology play a major role in structuring salmonid distributions, by influencing the distributions of suitable spawning habitat (Montgomery et al., 1999; Buffington et al., 2004). Spatially-varying catchment characteristics also play a strong role in regulating stream acidity, through two main mechanisms. First, terrestrial weathering processes in the watershed largely determine the acid-neutralizing capacity of groundwater and soil water, ultimately determining the capacity of receiving water bodies to buffer against acidification (Johnson et al., 1981). Second, particularly in areas with organic-rich soils including much of the boreal zone, soils may also supply the majority of acidity to surface waters in the form of natural organic acids (Hemond, 1990; Erlandsson et al., 2011).

This project was undertaken to determine the environmental factors influencing brown trout distributions at multiple spatial scales, including whole-catchment characteristics and local site chemistry (acidity), physical habitat and the density of other fish species as potential predictors. We used as a case study the Krycklan catchment, a $67 \mathrm{~km}^{2}$ boreal watershed in northern Sweden (Buffam, 2007; Laudon et al., 2013). In this region, stream water acidity is strongly influenced by the concentrations of naturally occurring soil-derived organic acids (Laudon et al., 2000; Erlandsson et al., 2011), distinguishing the current study from previous research on acidity-fish distribution relationships in other more clear water stream networks (e.g., Hesthagen et al., 1999; Baldigo and Lawrence, 2000; Kocovsky and Carline, 2005). In these humic-rich boreal streams, inorganic aluminum concentrations rarely exceed published toxicity thresholds due to the effective binding of $\mathrm{Al}$ in non-toxic forms by dissolved organic matter (Cory et al., 2006), but pH drops in many streams from above 6.0 at baseflow to below 5.0 during spring flood acid episodes (Buffam et al., 2007), driven largely by an increase in naturally occurring organic acids (Bishop et al., 2000; Laudon et al., 2000).

Our central research questions were: (1) How important is stream acidity relative to local physical habitat and presence of other fish species in influencing brown trout distributions within this boreal stream network? (2) Are brown trout distributions within this stream network predictable from wholecatchment landscape characteristics, and to what degree is this correlation mediated by measurable local-scale stream habitat characteristics?

\section{MATERIALS AND METHODS}

\section{Site Description}

The study area is the upper $67 \mathrm{~km}^{2}$ of the Krycklan River catchment in northern Sweden (Figure 1). This catchment includes the Vindeln experimental forests, where climate data have been monitored at the Svartberget Research Station $\left(64^{\circ}\right.$ 


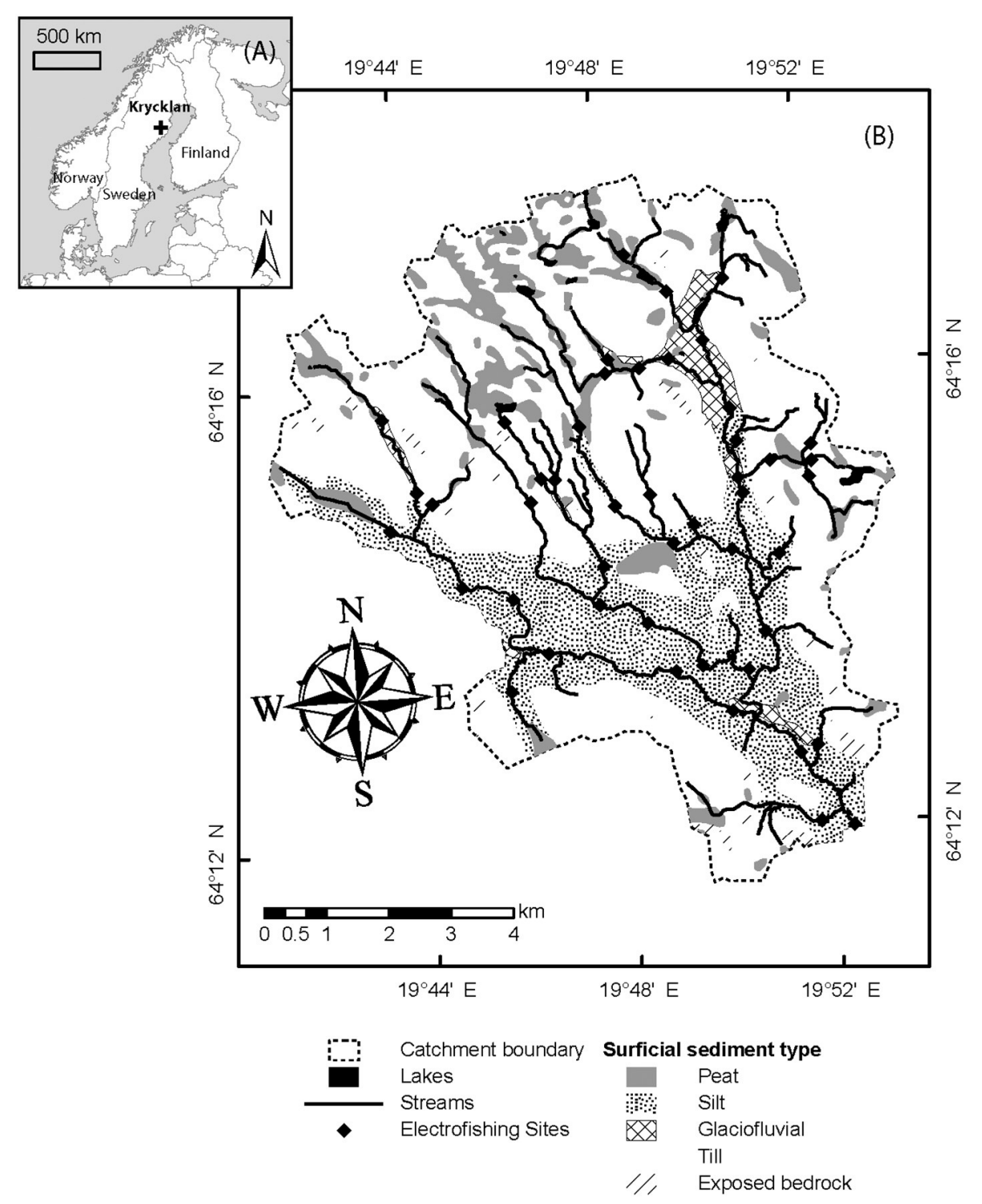

FIGURE 1 | Maps of (A) location within Sweden and (B) Krycklan catchment with surficial sediment coverage and electrofishing sites ( $N$ = 47) marked. Sediment types are described in more detail in the text. Chemistry sampling site locations during spring flood and winter baseflow were similar to those shown here, but with some sites up to a few $100 \mathrm{~m}$ from the respective fish sampling site.

$\left.14^{\prime} \mathrm{N}, 19^{\circ} 46^{\prime} \mathrm{E}\right)$ since 1980 . Annual mean air temperature is $+1^{\circ} \mathrm{C}\left(-10^{\circ} \mathrm{C}\right.$ in January, $+15^{\circ} \mathrm{C}$ in June $)$ with about $600 \mathrm{~mm}$ annual mean precipitation, of which one-third falls as snow (Ottosson Löfvenius et al., 2003). Snow cover is present for 171 days on average (1980-1999), and spring snowmelt is the dominant hydrological event, exporting up to half of the annual stream flow during a 3-6 week period in April-May. Within the experimental forests, soil hydrologic parameters, stream flow and stream chemistry have been monitored in the 50 ha Svartberget subcatchment since 1980. In 2003 an expanded monitoring program was established to study links between spatial and temporal patterns in stream chemistry and biota across a range of spatial scales, from small headwaters/hillslopes up to the
$67 \mathrm{~km}^{2}$ Krycklan outlet (Buffam et al., 2008; Laudon et al., 2013).

At the time of the study the area received $c a .1 .5 \mathrm{~kg} \mathrm{ha}^{-1}$ $\mathrm{yr}^{-1}$ each of $\mathrm{S}$ (as $\mathrm{SO}_{4}^{2-}$ ) and $\mathrm{N}$ (as $\mathrm{NO}_{3}^{-}$) from atmospheric deposition (Laudon et al., 2021). Deposition peaked in the 1970s at about $10 \mathrm{~kg} \mathrm{ha}^{-1} \mathrm{yr}^{-1}$ of $\mathrm{S}$, which was less than a quarter of that experienced in southwestern Sweden (Mylona, 1996). In the study region the pulse of stream water acidity associated with this annual episode is typically derived primarily from an increase in naturally occurring organic acids in conjunction with the dilution of ANC (acid neutralizing capacity), with a smaller contribution from anthropogenically-derived acids (Bishop et al., 2000; Laudon et al., 2000). 
The Krycklan study catchment (Laudon et al., 2013) is underlain by gneissic bedrock and ranges from 126 to 369 meters above sea level (Figure 1). The catchment is forested primarily with mature Scots pine (Pinus sylvestris) in dry upslope areas and Norway spruce (Picea abies) in wetter, low-lying areas and some deciduous shrubs and trees in the riparian forest along larger streams. The forested landscape is interspersed with patches of acidic sphagnum-dominated peat wetlands, making up $9 \%$ of the total catchment area. In the upper reaches of the catchment, the surficial quaternary deposits are dominated by till varying in thickness up to tens of meters, and iron-podzol soils are common (Ivarsson and Johnsson, 1988). The lower 55\% of the catchment is below the highest post-glacial coast line, and contains extensive deposits of fine-grained silty or sandy sediments which originated as a postglacial river delta, as well as coarse-grained glaciofluvial deposits found near the former coast line (Tamm and Malmström, 1926; Ivarsson and Johnsson, 1988). In simplified terms the streams in this catchment represent a gradient from small, acidic streams underlain by till at higher altitudes, to larger more well-buffered streams underlain by fine sand/silt (Buffam et al., 2008; Tiwari et al., 2017). Brown trout (Salmo trutta), brook trout (Salvelinus fontinalis) and bullhead (Cottus gobio) are common in many of the streams.

\section{Fish Community Composition}

The overall sampling strategy was designed to give a distributed spatial coverage of the Krycklan stream network representing a range of stream sizes and habitat conditions. Fish assemblages were assessed by electrofishing 47 locations distributed throughout the stream network (Figure 1). Fishing was carried out during low-water conditions in late summer 2005 (August 31st-October 5th) to ensure that age-0 fish (fish born within the past year) had emerged and dispersed. A generatorpowered electro shocker (Lugab, Luleå, Sweden) with a constant direct current of $800 \mathrm{~V}$ was used, and a length of $50 \mathrm{~m}$ was typically fished, with the sampled area ranging from 30 to 350 $\mathrm{m}^{2}$ depending upon stream width. Standard electrofishing protocols for Swedish streams were followed (Degerman and Sers, 1999), and populations of each fish species were estimated quantitatively using the multiple-pass depletion method (Seber, 1982; Bohlin et al., 1989). Three successive fishing passes of 15-20 min were carried out, unless no fish were caught in the first pass, in which case no further passes were performed. All fish collected were identified to species and measured in length $( \pm 1 \mathrm{~mm})$ before being returned to the stream following the third pass. Sampling was repeated at four of the sites at the end of the period (3-4 weeks after the first sampling) to check for consistency over time. For all four of these sites, exactly the same fish assemblages and similar densities of each species were recorded for the two sampling occasions. For statistical purposes, only the first sampling occasion was used in data analysis.

\section{Fish Population Density Calculations}

Using the three-pass electrofishing data, population density of each fish species was calculated using the Moran-Zippin maximum likelihood method (Moran, 1951; Zippin, 1956) as described in Bohlin et al. (1989). Catchability (p), the probability of capture of an individual (Seber, 1982), was estimated by iterative calculation from the three successive passes. The population size $(\mathrm{N})$ at a given sampling site was then calculated from the total catch (T) using equation 1 (Bohlin et al., 1989), where $\mathrm{K}$ is the number of passes:

$$
N=T\left[1-(1-p)^{K}\right]^{-1}
$$

As brown trout which were the focus of this study, we additionally divided the brown trout into two age categories based on body length. Based on the clear bimodal distribution of brown trout lengths, we determined that brown trout with length $<90 \mathrm{~mm}$ were age-0 (young-of-the-year), while those with length $>90 \mathrm{~mm}$ were designated age-1+ (adults or juveniles $>1$ year in age). Separate estimates of population density were made for trout age- 0 and age- $1+$ brown trout at each site, by dividing the estimated population number by the sampled area in $\mathrm{m}^{2}$.

\section{Water Chemistry}

Water samples were collected at each of the 47 sites (Figure 1) at the time of electrofishing (September 2005) and additionally at most sites during winter baseflow ( $N=41$, February 2005) and spring flood $(N=44$, April 22, 2004). The reduced number of sampled chemistry sites during these periods were caused by inaccessibility due to snow cover/complete freezing of 6 small headwaters during winter, and extremely high flow restricting accessibility to 3 sites during the spring flood. The two additional sampling occasions were selected to represent the extreme conditions experienced annually in Swedish boreal streams, both in terms of discharge and in terms of $\mathrm{pH}$. Late winter base flow is a period of sustained low flow associated with high $\mathrm{pH}$, while the spring flood period typically gives rise to the highest annual flows and the longest period of sustained low $\mathrm{pH}$ (Laudon et al., 2000). Data from 15 sites where stream $\mathrm{pH}$ was measured more frequently indicated that these sampling occasions represented well the entire transition between the extreme situations winter base flow and peak spring flood (Buffam et al., 2007, 2008).

At each sampling occasion, samples for $\mathrm{pCO}_{2}$ headspace gas analysis were collected in $\mathrm{N}_{2}$-filled $60 \mathrm{~mL}$ glass vials sealed with bromobutyl rubber septa, while samples for all other analyses were collected with multiple rinses in acid-washed $250 \mathrm{~mL}$ high-density polyethylene bottles. Following collection, water samples were kept dark and cool until they were subsampled and preserved as appropriate for chemical analyses. Chemical analytical methods are described in detail in Buffam et al. (2007) including information on precision and QA/QC procedures, but a short summary follows. $\mathrm{pH}$ (at natural $\mathrm{pCO}_{2}$, not airequilibrated) was measured using a ThermoOrion Ross 8102 low-conductivity combination electrode. Headspace $\mathrm{pCO}_{2}$ was analyzed on a Perkin Elmer Autosystem Gas chromatograph (GC-FID), and $\mathrm{HCO}_{3}^{-}$concentration was calculated from $\mathrm{pCO}_{2}$, $\mathrm{pH}$, and stream water temperature as described in Laudon and Buffam (2008). Dissolved organic carbon (DOC) was measured using a Shimadzu TOC-V $\mathrm{V}_{\mathrm{PCH}}$ analyser. The concentration of dissociated organic acids $\left(\mathrm{OA}^{-}\right)$was calculated from DOC and $\mathrm{pH}$ using a triprotic model (Hruška et al., 2003) with pka1 = 3.04 , pka2 $=4.42$, pka3 $=6.7$ and an overall site density of 
$10.2 \mu \mathrm{eq} / \mathrm{mg}$-C. Dissolved concentrations of the elements $\mathrm{K}, \mathrm{Mg}$, $\mathrm{Na}, \mathrm{Ca}, \mathrm{Al}, \mathrm{Fe}$, and $\mathrm{Si}$ were analyzed by inductively-coupled plasma optical emission spectroscopy (ICP-OES) on a Varian Vista Ax Pro instrument. Inorganic aluminum $\left(\mathrm{Al}_{\mathrm{i}}\right)$ was modeled from $\mathrm{Al}_{\text {tot }}$ using the Windermere Humic Acid Model (WHAM) (Tipping, 1994), calibrated as described in Cory (2006) to $\mathrm{Al}_{\mathrm{i}}$ measurements made in the Krycklan stream network. Dissolved anions $\left(\mathrm{SO}_{4}^{2-}, \mathrm{Cl}^{-}, \mathrm{NO}_{3}^{-}\right.$, and $\left.\mathrm{F}^{-}\right)$were analyzed on a Dionex DX-300 or DX-320 ion chromatograph system. Base Cation (BC) concentration was calculated as the sum of the major cations $\mathrm{K}^{+}$, $\mathrm{Mg}^{2+}, \mathrm{Na}^{+}$, and $\mathrm{Ca}^{2+}$ concentrations expressed as $\mu$ eq $\mathrm{L}^{-1}$ of charge, with the assumption that these elements were present in their free ionized form. Strong Acid Anion (SAA) concentration was calculated as the sum of the major anions $\mathrm{SO}_{4}^{2-}$ and $\mathrm{Cl}^{-}$ expressed as $\mu \mathrm{eq} \mathrm{L}^{-1}$ of charge, as $\mathrm{NO}_{3}^{-}$and $\mathrm{F}^{-}$were found to have negligible contributions to overall charge balance. AcidNeutralizing Capacity (ANC) was calculated as BC-SAA.

\section{Potential Spatial Extent of Brown Trout Based on Published pH Thresholds}

For visualization of the potential spatial extent of brown trout based on stream water acidity, we grouped Krycklan stream sites into four $\mathrm{pH}$ categories for each time period: $\mathrm{pH}<5.0$ (unsuitable for brown trout), 5.0-5.5 (limited suitability), 5.5-6.0 (intermediate suitability), or $>6.0$ (no $\mathrm{pH}$ restrictions). This division was justified based on past studies of brown trout $\mathrm{pH}$ thresholds, foremost a review of 17 studies with brown trout (Baker and Christensen, 1991) which proposed a critical episodic $\mathrm{pH}$ threshold for brown trout between $\mathrm{pH} 4.8$ and 5.4 in poorly buffered, low DOC waters which had been subjected to acidification. Other studies focusing on baseflow rather than episodic $\mathrm{pH}$ have suggested baseflow thresholds around $\mathrm{pH}$ 5.76.0 for brown trout (e.g., Andersson and Andersson, 1984; Baldigo and Lawrence, 2001; Kocovsky and Carline, 2005) based on observed distributions in the field correlated with measurements of $\mathrm{pH}$ at mean or baseflow conditions. In situ bioassays with 1 year old brown trout during spring flood in Krycklan streams also found that mortality was likely ( $>80 \%$ probability) in streams that drop below $\mathrm{pH} 4.8$, with an indication that there was an increased probability for mortality (20\% probability) occurring already at about pH 5.4 (Serrano et al., 2008).

\section{Site Physical Characteristics/Habitat}

At each electrofishing site, local physical habitat was characterized on the day of fishing by the standard method used by the Swedish National Board of Fisheries (Degerman and Sers, 1999). A brief description of the method follows, with additional details included in Table 1. Stream width was measured at 3-5 points and averaged to give mean width for the electro fished section. Maximum stream depth was estimated for the electro fished area, and the degree of shading of the stream was estimated to the nearest $10 \%$. Water color and streambed heterogeneity were classified, and bottom substrate size classes were recorded. Water temperature was measured, and the density of large woody debris (LWD,
$>10 \mathrm{~cm}$ diameter and $>50 \mathrm{~cm}$ length) was calculated by counting all LWD in the electro fished area. Dominant underwater vegetation type was noted, as were dominant and subdominant tree species in the near-stream zone. Map information was used to supplement the habitat survey data and further characterize the local site conditions: Surface sediment types within $100 \mathrm{~m}$ of the site were identified from a 1:100,000 Quaternary deposits map (Geological Survey of Sweden, Uppsala, Sweden), stream order was calculated using a 1:100,000 road map (Lantmäteriet, Gävle, Sweden), and altitude was identified from the $50 \mathrm{~m}$ resolution DEM (Lantmäteriet, Gävle, Sweden). For statistical analyses, all categorical variables were transformed into numerical scores as described in Table 1.

\section{Catchment Delineation and Characterization}

Map-derived catchment characteristics (Table 2) were determined along the Krycklan stream network for each of the 47 electrofishing sites based on catchment delineation using $50 \mathrm{~m}$ resolution gridded elevation data (DEM) as described in Buffam et al. (2008). As attributes, we used map characteristics including surface sediment type from the 1:100,000 scale digital Quaternary deposits coverage map (Geological Survey of Sweden, Uppsala, Sweden) and land-cover type from a 1:12,500 scale digital land-cover map (Lantmäteriet, Gävle, Sweden). From the Quaternary deposits map, categories sand and gravel were rare $(<0.5 \%$ of areal coverage in entire catchment) and were excluded from statistical analyses. From the land-cover map, the categories open and arable were lumped to create an "open or arable" category. Forest information was estimated from satellite data from the national forest inventory by the $\mathrm{k}$ nearest neighbor $(\mathrm{kNN})$ method (Reese et al., 2003). Other parameters were calculated directly from the DEM (Table 2). In total, 20 different catchment characteristics were used to characterize each stream grid cell. For the sampled stream sites $(N=47)$ catchment characteristics were then extracted from the appropriate grid cells along the stream network.

\section{Data Analysis}

The variation in age- 0 and age- $1+$ brown trout were together correlated with four separate sets of environmental predictor variables with multivariate Redundancy Analysis (RDA) using CANOCO for Windows 4.54. The potential predictor variables included local site physical characteristics (Table 1), whole catchment characteristics (Table 2), density of other common fish species, and stream chemistry during three different time periods. Prior to all statistical analyses, non-normally distributed variables were transformed as appropriate (arcsine transformation for proportional catchment cover variables, and log transformation for catchment area and selected site and chemistry parameters). Initial examination of the density data with Detrended Correspondence Analysis indicated that RDA was the appropriate multivariate analysis to use since the data were linearly distributed (gradient length $<3$ ). The significance level of each environmental variable was first 
TABLE 1 | Median (range) of local site/habitat characteristics for 47 electrofishing sites.

\begin{tabular}{|c|c|}
\hline \multicolumn{2}{|l|}{ Site characteristics - field survey } \\
\hline Stream width $(\mathrm{m})$ & $1.0(0.4-7.0)$ \\
\hline Max depth (m) & $0.6(0.1-1.3)$ \\
\hline Water temperature $\left({ }^{\circ} \mathrm{C}\right)$ & $7.7(4.0-10.4)$ \\
\hline Water color a & $2(1-3)$ \\
\hline Streambed heterogeneity ${ }^{b}$ & $2(1-3)$ \\
\hline \multicolumn{2}{|l|}{ Substrate type ${ }^{c}$} \\
\hline Fine sediment & $0(0-3)$ \\
\hline Sand & $2(0-3)$ \\
\hline Gravel & $2(0-3)$ \\
\hline Boulder & $0(0-3)$ \\
\hline Bedrock & $0(0-3)$ \\
\hline \multicolumn{2}{|l|}{ Underwater vegetation type ${ }^{d}$} \\
\hline Sphagnum mosses & $0(0-1)$ \\
\hline Attached filamentous green algae & $0(0-1)$ \\
\hline Large woody debris (nr per $100 \mathrm{~m}^{2}$ ) & $5(0-50)$ \\
\hline \multicolumn{2}{|l|}{ Dominant riparian tree type ${ }^{e}$} \\
\hline Coniferous (spruce, pine) & $1(0-2)$ \\
\hline Deciduous (birch, alder, willow) & $2(1-3)$ \\
\hline Degree of shading (\%) & $50(10-75)$ \\
\hline \multicolumn{2}{|c|}{ Site characteristics - map information } \\
\hline Altitude (m) & $198(126-287)$ \\
\hline Stream order & $2(1-4)$ \\
\hline \multicolumn{2}{|c|}{ Surficial sediment type within $100 \mathrm{~m}^{f}$} \\
\hline Till & $0(0-3)$ \\
\hline Peat & $0(0-3)$ \\
\hline Coarse silt & $0(0-3)$ \\
\hline Fine silt & $0(0-3)$ \\
\hline Glaciofluvial deposits & $0(0-3)$ \\
\hline \multicolumn{2}{|c|}{ 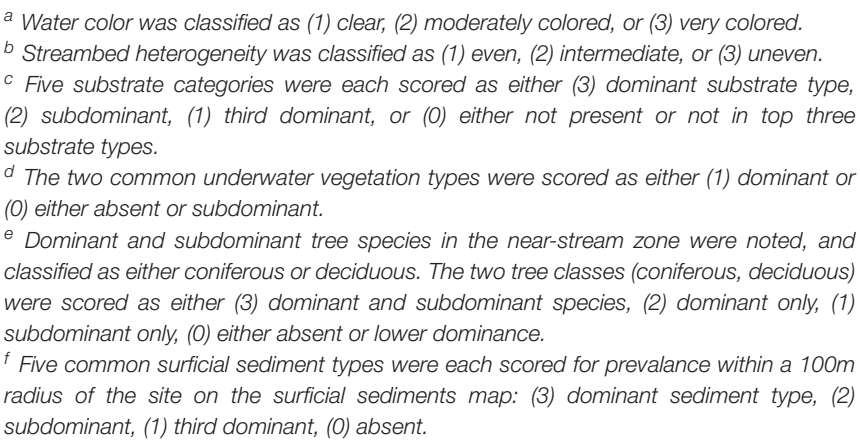 } \\
\hline
\end{tabular}

TABLE 2 | Median (range) of catchment characteristics for 47 electrofishing sites.

Surficial sediments (\%)

Till

$62(45-99)$

Peat

$13(0-41)$

Silta

2 (0-39)

Glaciofluvial deposits ${ }^{b}$

$0(0-9)$

Shallow till

Exposed bedrock

$8(1-33)$

$1(0-6)$

Land cover (\%)

Forest

84 (58-99)

$12(0-37)$

$2(0-11)$

$1(0-6)$

$0(0-12)$

Lake

Forest inventory

Birch volume $\left(\mathrm{m}^{3} \mathrm{ha}^{-1}\right)$

$13(8-21)$

Spruce volume $\left(\mathrm{m}^{3} \mathrm{ha}^{-1}\right)$

37 (18-113)

$58(30-87)$

57 (37-94)

Mean tree stand age (yr)

79 (3-100)

$10(4-16)$

277 (213-299)

$3.2(0.5-66.8)$

$0.9(0.2-2.6)$

Median subcatchment size $\left(\mathrm{km}^{2}\right)^{\mathrm{d}}$

a fine silt and coarse silt/fine sand.

${ }^{b}$ glaciofluvial deposits of coarse sorted sediments (primarily gravel and cobble).

c percent of catchment with altitude above $257.5 \mathrm{~m}$, which is the local altitude of the furthest extent of the sea following the last deglaciation.

${ }^{d}$ median of the distribution of subcatchment areas draining into the stream cells within a given catchment.

Eilertsen, 1994). In this case, three separate pRDA analyses were run to compare variance in brown trout density explained due to: (1) catchment characteristics vs. site characteristics, (2) catchment characteristics vs. stream chemistry, and (3) site characteristics vs. stream chemistry. Biotic factors (density of other common fish species) were excluded from the pRDA analysis because these variables were found to have very weak or no association with brown trout distributions in the initial RDA (see Results section).

\section{RESULTS}

tested individually by comparison with a randomized Monte Carlo simulation with 499 permutations using the routine provided in CANOCO. Significant variables $(p<0.05)$ were then included as potential predictors. Forward selection was used to sequentially select variables which significantly improved the model ( $p<0.05$ for inclusion). Partial RDA (pRDA) analysis was performed in order to calculate the degree of shared explained variance between the different environmental predictor groups. The pRDA analysis explicitly partitions explained variance between different predictor groups and also calculates variation shared between the groups (Økland and

\section{Local Site/Habitat Characteristics}

In the Krycklan watershed there is a gradient from small streams underlain by till sediments to larger streams underlain by coarse silt (for details see Ågren et al., 2007; Buffam et al., 2008; Laudon et al., 2013). Surficial sediment types (Figure 1; Table 2) showed a characteristic trend along this altitudinal/stream size gradient, with forested till and peat wetlands in the upper reaches giving way to fine-grained silty sediments in the lower altitudes. Along this gradient, substrate shifted from gravel, boulder, and bedrock to fine sediment or sand, while dominant riparian tree type shifted 
TABLE 3 | Median (range) of chemistry parameters for the electrofishing sites during three different sampling periods.

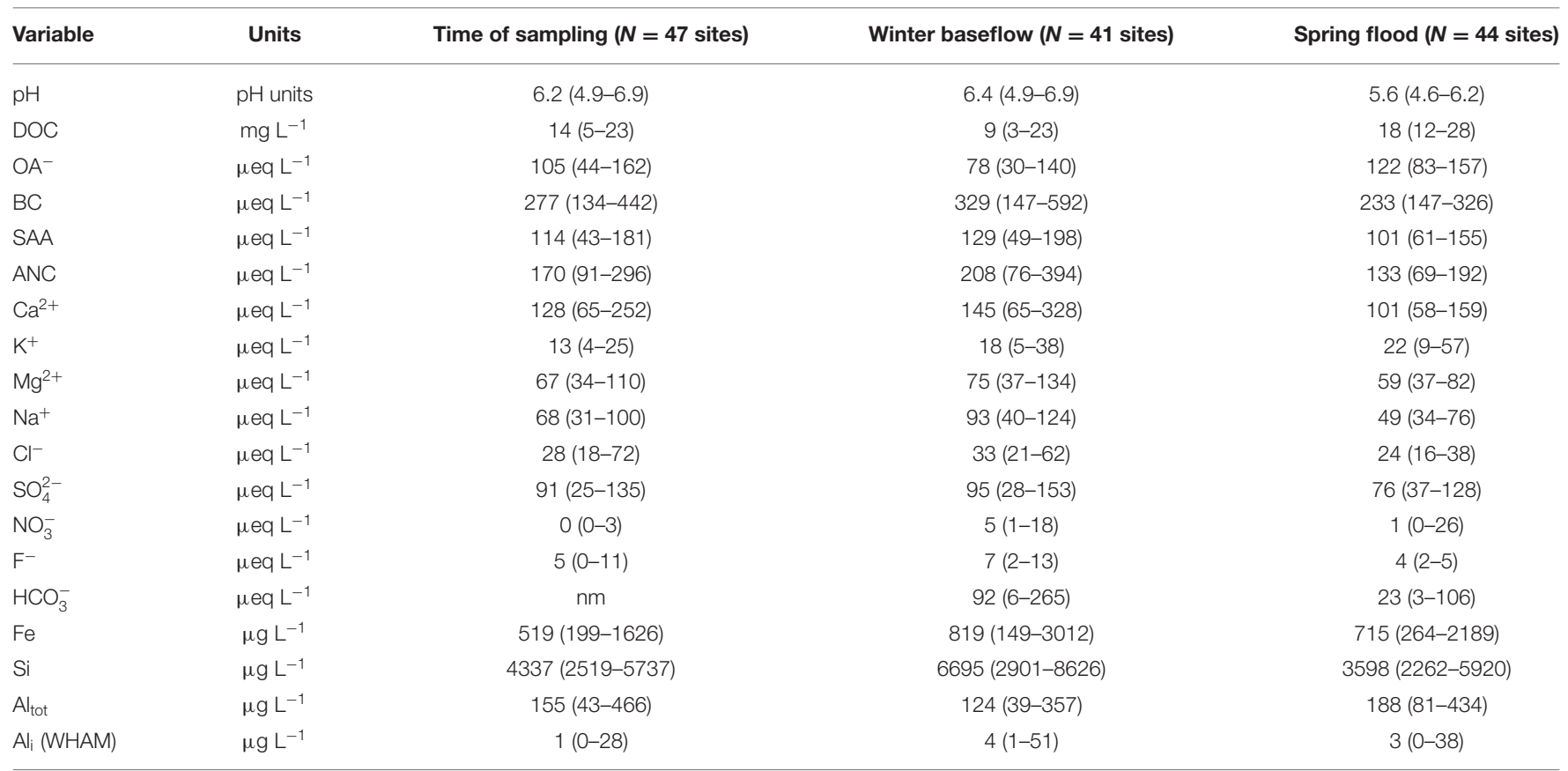

$O A^{-}$, dissociated organic acids (weak+strong); BC, base cations; SAA, strong acid anions; ANC, acid neutralizing capacity, BC-SAA.

$A l_{i}$, Concentration of cationic (labile) inorganic aluminum, modeled using WHAM.

$\mathrm{nm}$, not measured.

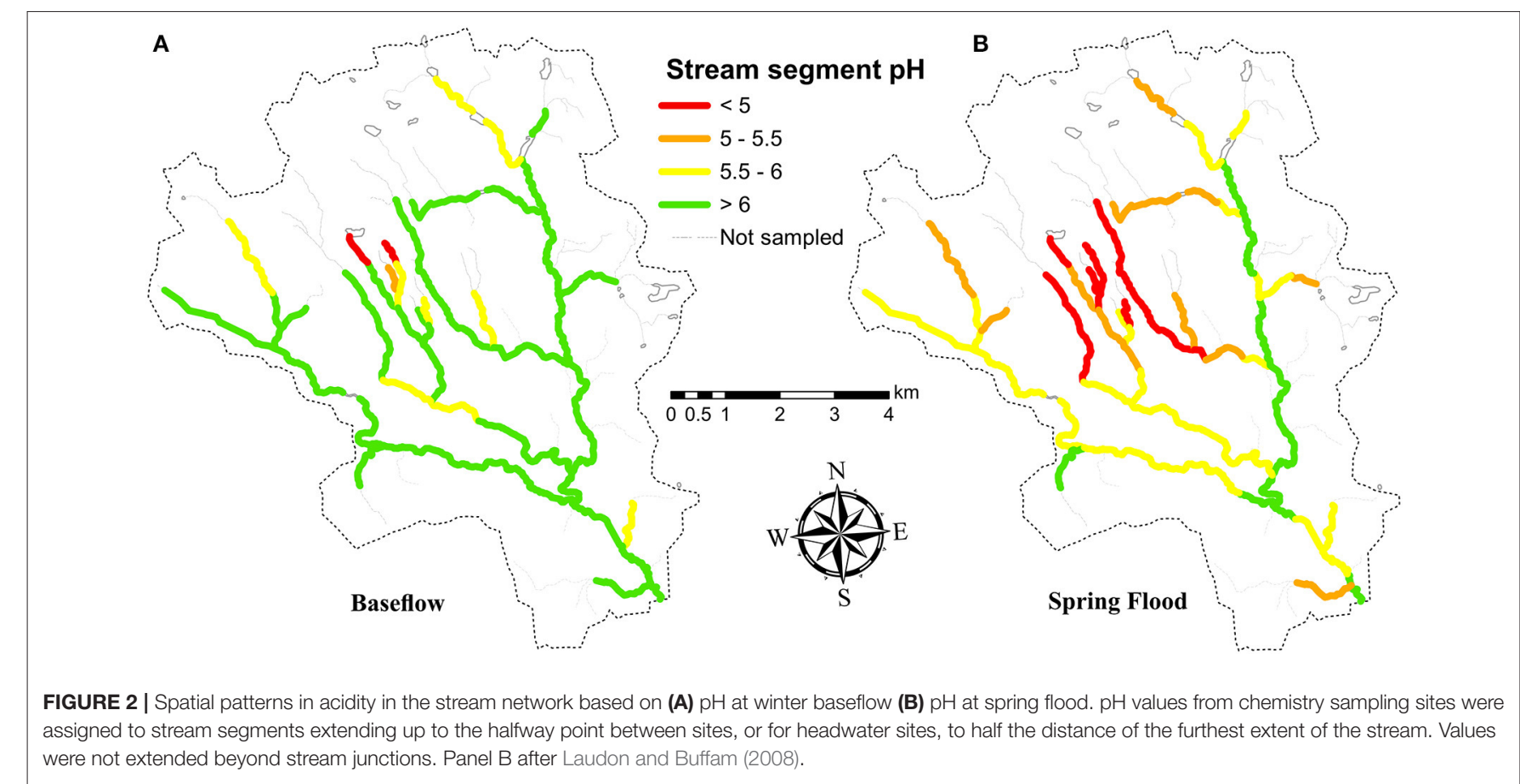

from coniferous to deciduous. Attached filamentous green algae (Table 1) was more common in high altitude streams in areas of till and glaciofluvial deposits, and less common in lower altitude silty streams, while sphagnum mosses were common in areas underlain by peat.

\section{Stream Chemistry and Potential Brown Trout Distribution Based on $\mathrm{pH}$ and $\mathrm{Al}_{\mathrm{i}}$}

For nearly all of the sites, $\mathrm{pH}$ at the time of fishing was lower than winter base flow $\mathrm{pH}$ (mean difference $0.24 \pm 0.31 \mathrm{pH}$ units) but higher than spring flood $\mathrm{pH}$ (mean difference $0.57 \pm 0.30 \mathrm{pH}$ 
TABLE 4 | Fish caught during the electrofishing survey ( $N=47$ sites).

\begin{tabular}{|c|c|c|c|}
\hline Species & Latin name & Nr fish & Nr sites present \\
\hline Brook trout & Salvelinus fontinalis & 531 & 35 \\
\hline Bullhead & Cottus gobio & 242 & 16 \\
\hline Brown trout & Salmo trutta & 87 & 17 \\
\hline Brook lamprey & Lampetra planeri & 69 & 11 \\
\hline Burbot & Lota lota & 9 & 5 \\
\hline Northern pike & Esox lucius & 2 & 2 \\
\hline Perch & Perca fluviatilis & 2 & 1 \\
\hline
\end{tabular}

units). The average chemistry at the time of fishing was bracketed by that of winter base flow and spring flood $(p<0.05$, paired 2-tailed $t$-test) for all analytes except, $\mathrm{K}^{+}, \mathrm{Fe}$, and $\mathrm{NO}_{3}^{-}$and modeled $\mathrm{Al}_{\mathrm{i}}$. These four were lower $(p<0.05$, paired 2 -tailed $t$-test) at the time of fishing than during the other two periods (Table 3).

The relatively high $\mathrm{pH}$ at most sites at the time of fishing and during winter base flow meant that almost all streams were suitable for brown trout based on $\mathrm{pH}$ during these periods (Figure 2). During spring flood however, most sites experienced a $\mathrm{pH}$ drop (range 0.0 to $1.7 \mathrm{pH}$ units lower than winter base flow), resulting in a decreased potential trout distribution based on $\mathrm{pH}$. At the time of spring flood, 12 of the 47 sites had a $\mathrm{pH}$ between 5.0 and 5.5, while six sites had a pH below 5.0. The lowest $\mathrm{pH}$ occurred primarily in headwaters, especially in the till and peat-dominated central tributaries in the Krycklan catchment (Figure 2). Although total aluminum $\left(\mathrm{Al}_{\text {tot }}\right)$ was moderately high in places (median value $>100 \mu \mathrm{g} \mathrm{L}^{-1}$ for each sampling period), modeled inorganic aluminum $\left(\mathrm{Al}_{\mathrm{i}}\right)$ concentrations, with a maximum value of $51 \mu \mathrm{g} \mathrm{L}^{-1}$ for the three chemistry samplings, did not exceed published toxicity thresholds (e.g., Fivelstad and Leivestad, 1984; Sadler and Lynam, 1987).

\section{Fish Species Found and Spatial Distribution of Brown Trout}

Seven different fish species were found in total (Table 4), of which four species were common (found at 10 or more sites). The most widely distributed was brook trout, which was found throughout the stream network including in some of the smallest most acidic headwater streams, while bullhead, and brook lamprey were common in larger more well-buffered streams (Buffam, 2007). Brown trout were the third most abundant species and were found at 17 sites scattered throughout the watershed (Figure 3). Age- $1+$ brown trout were found at 16 sites, while age- 0 brown trout were only found at 6 sites, 5 of which were grouped in one region in the eastern portion of the catchment, encompassing $<4 \mathrm{~km}$ of total stream length (Figure 3). Where present, age0 and age- $1+$ brown trout densities ranged from 1-13 to 1-12 individuals $/ 100 \mathrm{~m}^{2}$, respectively. Brown trout were absent from the two main tributaries in the center of the Krycklan catchment, which are primarily underlain by till (Figure 1) and experience high acidity during the spring flood episode (Figure 2).

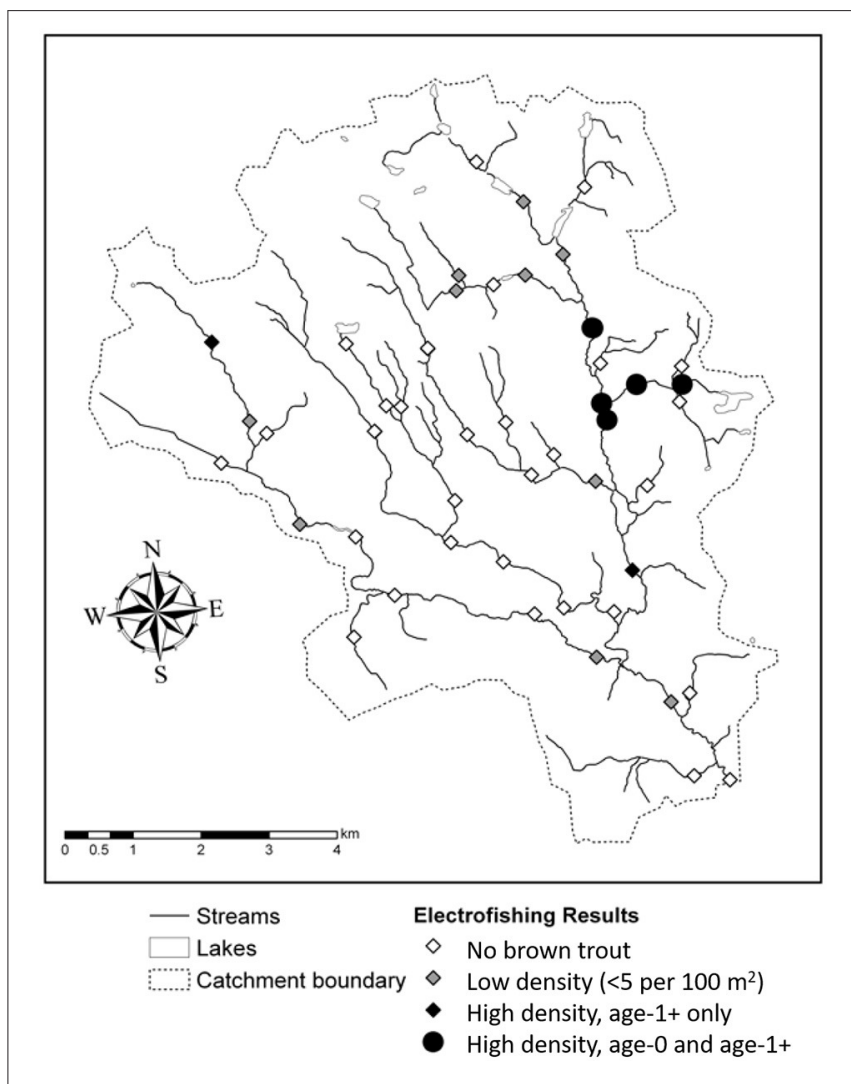

FIGURE 3 | Observed distribution of brown trout at the time of electrofishing (September 2005).

\section{Associations of Brown Trout With Environmental Characteristics at Different Spatial Scales}

Of 103 environmental variables tested (Tables 1-4), 21 were individually significantly correlated with the variation in age0 and age- $1+$ brown trout densities (Table 5). From the group of whole catchment variables, the proportion of coarse sorted sediments (primarily glaciofluvial), the proportion of lakes in catchment, and the mean density of pine forest in catchment together explained $43 \%$ of the total variance in age- 0 and age$1+$ brown trout distributions (Table 5, Model 1). The primary gradient in the RDA showed that high brown trout densities 
TABLE 5 | Summary of RDA analyses relating environmental variables to age-0 and age-1+ brown trout densities at 47 stream sites.

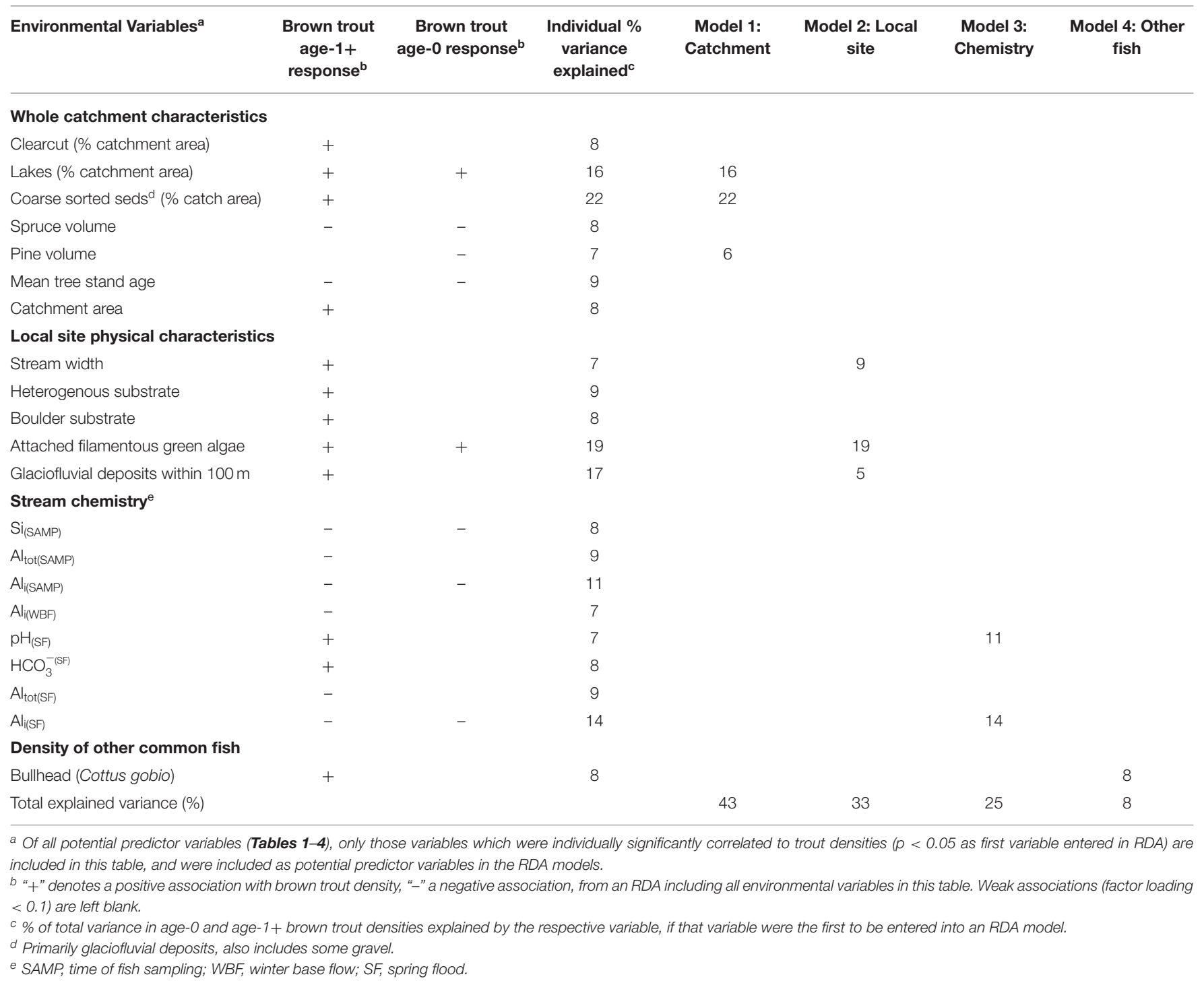

(both age classes) were associated with catchments with low pine density and a high coverage of glaciofluvial deposits and lakes. Other variables significantly correlated with trout distributions, but not selected for the best model because they did not add additional explanatory power, were: mean stand age, catchment area, clearcut coverage, and mean spruce density.

Local site physical characteristics were somewhat less strongly associated with brown trout distributions. Abundance of attached filamentous green algae, stream width, and presence of glaciofluvial deposits within $100 \mathrm{~m}$ of the site based on the Quaternary deposits map were all positively associated with brown trout densities and together explained 33\% of their variance (Table 5, Model 2). Other variables significantly correlated with trout distributions but not selected for the best model were: streambed heterogeneity and boulder substrate.

Stream chemistry was also significantly correlated with brown trout distributions. Spring flood $\mathrm{Al}_{\mathrm{i}}$ (WHAM-modeled) and spring flood $\mathrm{pH}$ were selected for the best-fit model, together explaining $25 \%$ of the variance in trout distributions (Table 5, Model 3), with brown trout having higher densities in high $\mathrm{pH}$, low $\mathrm{Al}_{\mathrm{i}}$ streams. Acidity measures were the chemistry parameters most consistently correlated with trout distributions, while of the three tested sampling periods, spring flood was the period with chemistry most tightly coupled to brown trout distributions (Table 5). In terms of their distribution relative to published acidity thresholds, brown trout were found at $40 \%$ of the sites whose $\mathrm{pH}$ did not drop below 5.0 during spring flood, but none of the 6 sites which experienced spring flood $\mathrm{pH}<5.0$, suggesting an avoidance of the streams that experienced very high acidity during storm events. And, although modeled $\mathrm{Al}_{\mathrm{i}}$ concentrations were generally low compared to published thresholds, brown trout were found at over half (15 of 26) sites with spring flood $\mathrm{Al}_{\mathrm{i}}<5 \mu \mathrm{g} / \mathrm{L}$, but only 1 of 18 sites with spring flood $\mathrm{Al}_{\mathrm{i}}>5 \mu \mathrm{g} / \mathrm{L}$, indicating a 
preference for sites where $\mathrm{Al}_{\mathrm{i}}$ stayed very low even during storm events.

Influence of other fish species on brown trout distributions was only weakly apparent from the RDA analysis. Bullhead (Cottus gobio) density was weakly positively correlated with age- $1+$ brown trout densities, explaining $8 \%$ of the variance. The densities of the other common species (brook trout, brook lamprey, burbot) were uncorrelated with brown trout densities. Because of the weak or non-existent correlations between the densities of other fish species and those of brown trout, the other fish species were not included as predictors in the partial RDA (pRDA) analysis.

\section{Combined Multivariate Model and Overlapping Predictive Power of Different Variables}

When the significant environmental variables from the wholecatchment, local site, and chemistry models (Table 5) were included as predictors in one combined RDA analysis of brown trout age- 0 and age- $1+$ densities (Figure 4), the total explained variance was $57 \%$, much less than the sum of the variance explained by the three individual models. Partial RDA (pRDA) analysis demonstrated high shared variance between the three groups of predictors, particularly whole catchment and local site physical characteristics (Figure 5). Catchment characteristics, local site characteristics, and water chemistry (acidity) uniquely accounted for 16,9 , and $8 \%$, respectively, of the variance in trout distributions, while the remaining variance could not be definitively assigned to a single predictor group but was shared between different predictor groups (Figure 5). Together, local site characteristics and stream chemistry explained $42 \%$ of the variance in trout distributions, similar to the $43 \%$ variance explained by whole catchment characteristics alone.

Keeping in mind the overlap in predictive power among different groups of environmental variables, the data did evince strong relationships between brown trout distributions and some individual habitat characteristics (Figure 6). All 6 of the sites underlain by glaciofluvial deposits contained brown trout (Figure 6B), while $<35 \%$ of the sites underlain by each of the other three major sediment types contained brown trout. Trout were also found at a high proportion of sites near $(<1 \mathrm{~km}$ distant along stream) glaciofluvial deposits (Figure 6C). Three other variables associated with trout presence (width, lakes in catchment, pine density in catchment) could be obtained or predicted directly from map characteristics, but one (presence of attached filamentous green algae) could not. Presence of attached algae was strongly correlated with trout distributions (Figure 6D): $67 \%$ of the sites with algae contained brown trout, while only $12 \%$ of the sites without attached algae contained brown trout.

The distribution of brown trout in Krycklan is consistent with combined restriction by both acidity and physical habitat, i.e., a multiple pass environmental filter. No brown trout were found at any of the 6 sites with prohibitively low $\mathrm{pH}$ ( $<5.0$ at spring flood). For the 12 sites with intermediate $\mathrm{pH}$ (5.0-5.5 at spring flood), brown trout were found in 4
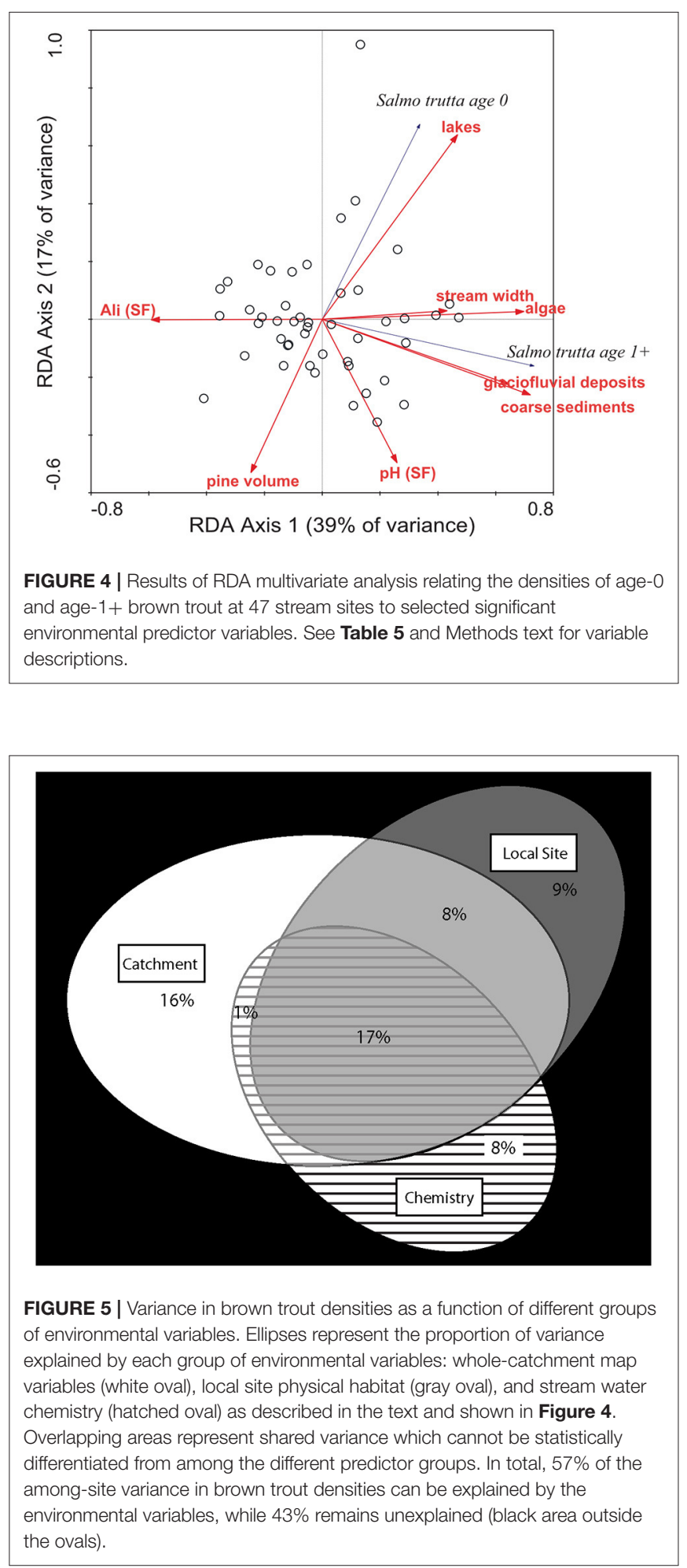

of 6 sites with glaciofluvial deposits present or nearby, but not found in any of the 6 sites where glaciofluvial deposits were more than $1 \mathrm{~km}$ distant. Where $\mathrm{pH}$ did not drop into the critical range even during spring flood $(\mathrm{pH}>5.5)$, trout 
A

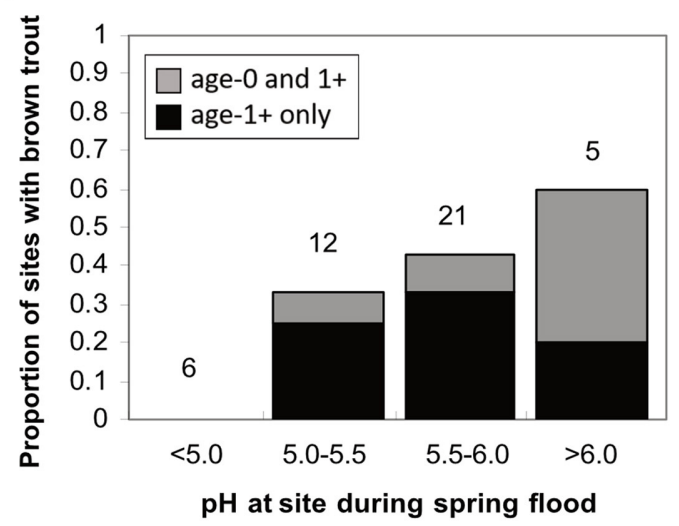

C

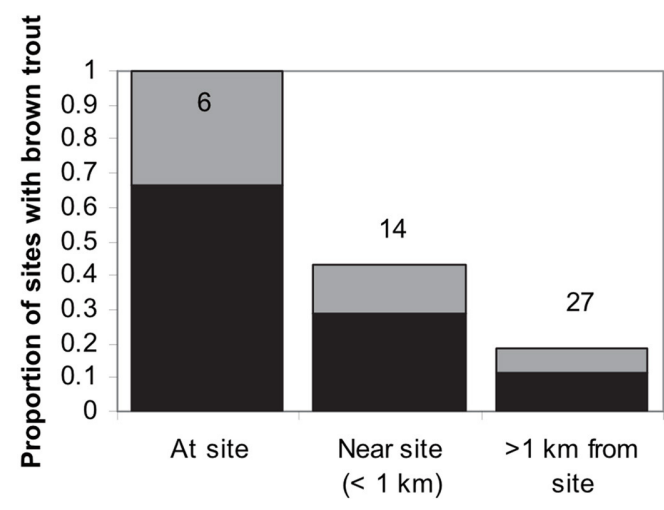

Nearest glaciofluvial deposits
B

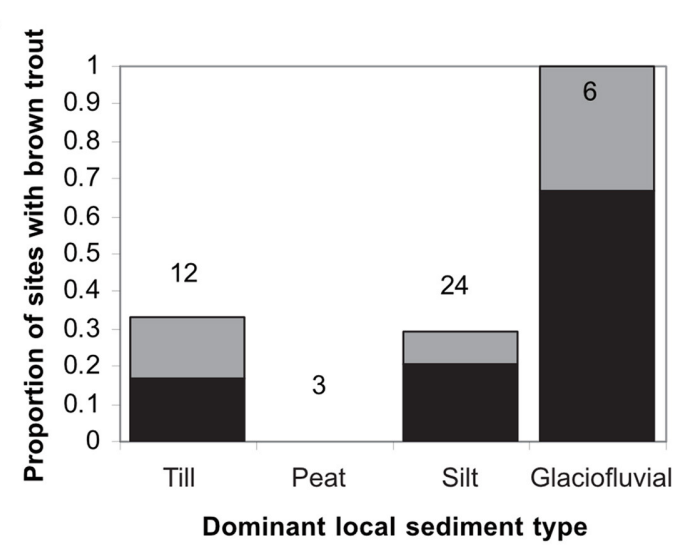

D

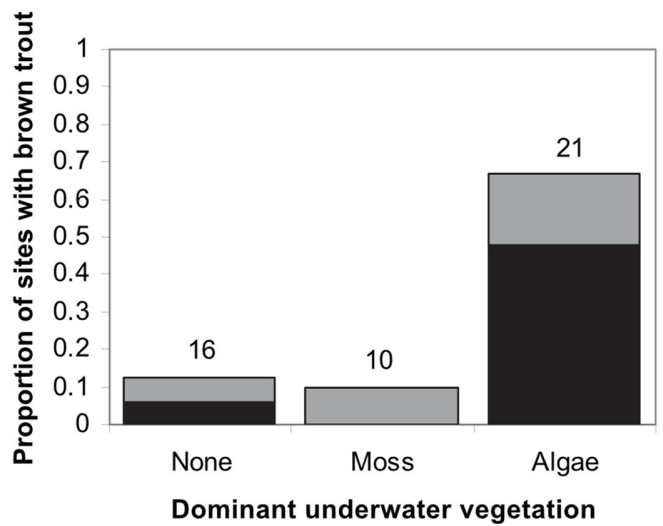

FIGURE 6 | Examples of relationships between individual habitat characteristics and the likelihood of finding brown trout present at a given site. Sites are grouped by: (A) $\mathrm{pH}$ at site during spring flood, (B) sediment type at site, (C) distance along stream to nearest surficial glaciofluvial deposit, (D) dominant type of underwater vegetation. Numbers above the bars represent total number of sites in a given category.

were also found even at greater distances from glaciofluvial deposits.

\section{DISCUSSION}

\section{Factors Influencing the Distribution of Brown Trout in a Boreal Stream Network}

Brown trout had a positive association with stream width, and were largely absent from small streams in our study, a commonly occurring pattern in brown trout distributions both in Europe and in North America (Vincent and Miller, 1969; Korsu et al., 2007). There are a number of factors which might be hypothesized to restrict brown trout distribution from the headwaters of Krycklan, including: (1) lack of suitable physical habitat (2) acidic chemistry in the small streams (3) competition from brook trout or bullhead (4) predation by northern pike or other fish (5) migration barriers preventing access.
In Krycklan, headwaters were primarily underlain by unsorted till which gave rise to gravel or larger substrate, while the largest streams occurred primarily in areas with sorted fine sediments. Brown trout require gravel for spawning and prefer larger substrate (Heggenes, 1988b), thus if substrate size were the primary organizing factor in Krycklan, brown trout would be expected to prefer smaller and avoid larger streams, which was not the case. Water temperature at the time of sampling was not correlated with stream size, nor with brown trout densities, suggesting against temperature as a major organizing factor in this case.

Headwaters are commonly more acidic relative to larger streams (Johnson et al., 1981; Kocovsky and Carline, 2005; Likens and Buso, 2006). This is the case for many of the tributaries in Krycklan (Buffam et al., 2008; Tiwari et al., 2017), and acidity alone likely restricted brown trout from a few headwater sites which were below $\mathrm{pH}$ 5.0. However, many of the headwater sites in question had acceptable $\mathrm{pH}$ and modeled 
$\mathrm{Al}_{\mathrm{i}}$ levels based on published threshold levels for brown trout (e.g., Baker and Christensen, 1991; Baldigo and Lawrence, 2001), so acidity alone cannot explain the lack of brown trout in the headwaters.

Brook trout had a wider distribution than brown trout (Table 4; Buffam, 2007) and did utilize the acidic headwaters in the central two tributaries of the Krycklan catchment (Buffam, 2007), which were completely lacking brown trout (Figure 3). Within the stream network brook trout and brown trout often coexisted and there was no correlation between their densities or other clear indication of a competitive interaction when all sites were considered. Similarly, a study of 1,000 streams distributed throughout Sweden found that brown trout densities did not differ based on presence/absence of brook trout (Öhlund et al., 2008). This does not rule out $\mathrm{pH}$-mediated competition at specific sites however, which has been implicated in the exclusion of brown trout from headwaters in North America (Kocovsky and Carline, 2005). The two species have different acid sensitivities, with brown trout parr and adults more sensitive than brook trout parr and adults (Baker and Christensen, 1991). Competition with brook trout in moderately acidic streams is thus a potential mechanism affecting brown trout distribution, and should be considered in future studies in the region.

Bullhead, a potential competitor for physical habitat based on studies of other stream-dwelling sculpin (Hesthagen and Heggenes, 2003), had a slight positive association with brown trout densities, suggesting that bullhead have minimal importance in influencing brown trout distributions at the scale of our analysis. Predation by northern pike has been implicated as a major controlling factor in the presence/absence of brown trout and other salmonids in northern Swedish lakes (Spens and Ball, 2008). Although pike were found at two of our stream sites in Krycklan (both near lake outlets), these sites also had brown trout, giving no indication of a strong influence of predation-though lakes with pike could restrict brown trout movement due to potential predation.

Limited connectivity between sites within the stream network is an important consideration in explaining the observed distribution of brown trout, as migration barriers can restrict trout to certain parts of a given stream network. However, during surveys of the entire stream length within the Krycklan stream network, only two migration barriers were found which would prevent passage even during periods of high water. Both barriers were on the western-most tributary (Åhedbäcken), and brown trout as well as brook trout were found both above and below the barriers. Thus, physical migration barriers are not thought to be the cause of the lack of brown trout in the central two tributaries and other headwaters (Figure 3), though chemical conditions including acidity may present a barrier.

We conclude that a combination of factors restrict brown trout from the headwater streams in Krycklan, including acidity and most likely competition with brook trout. Brook trout are less sensitive to acidity and thus may obtain a competitive advantage in small acidic streams (e.g., Kocovsky and Carline, 2005). Other biological or physical factors not directly examined in our study may play a role as well. For instance, variation in stream velocity or more subtle differences in seasonal water temperatures may restrict brown trout from headwaters in some small streams, or at least give brook trout a competitive advantage in headwaters (Vincent and Miller, 1969; Fausch and White, 1981; Öhlund et al., 2008).

\section{Role of Acidity in Restricting Brown Trout Distributions}

The observed distribution of brown trout was consistent with a community which avoids poorly buffered regions which become toxic during acid episodes, and matched well with $\mathrm{pH}$ thresholds for age-0+ brown trout mortality observed in bioassays during spring flood in the same catchment (Serrano et al., 2008). This could indicate that distributions are structured during episodes, and that the fish do not rapidly migrate upstream to recolonize the areas that became acidic. Or, the fish could be avoiding areas of intermediate acidity or particularly poorly buffered sites. Although stream-dwelling brown trout are generally stationary once established (e.g., Solomon and Templeton, 1976), they can migrate downstream or into well-buffered tributaries to avoid acidic episodes as observed with other salmonids (Carline et al., 1992; Vanoffelen et al., 1994; Baker et al., 1996; Ikuta et al., 2001). So, the presence of an individual trout at a given site does not necessarily mean that individual was there at the same site during the previous spring flood. However, the $\mathrm{pH}$ experienced during large summer/autumn rainfall events at a given site is typically similar to that experienced during spring flood (e.g., Laudon and Bishop, 2002; Laudon et al., 2021), so spring flood $\mathrm{pH}$ can be used as a proxy for a more general episodic $\mathrm{pH}$ level. Thus, the observed associations with spring flood $\mathrm{pH}$ and $\mathrm{Al}_{\mathrm{i}}$ are consistent with the hypothesis that brown trout distribution in this catchment is influenced by runoff-driven acid episodes.

Similar to other Swedish streams (Degerman and Lingdell, 1993), in the Krycklan stream network there was a reduced occurrence of brown trout in sites that experienced episodes in the $\mathrm{pH}$ 5.0-5.5 range, and brown trout were not found in sites which experienced spring flood $\mathrm{pH}<5.0$. Adult brown trout can survive episodes of $\mathrm{pH}<5.0$ in the absence of high $\mathrm{Al}_{\mathrm{i}}$ concentrations (Baker and Christensen, 1991; Reader et al., 1991), and brown trout eggs and yolk-sac fry are relatively insensitive to acidity (Reader et al., 1991; Serrano et al., 2008). However, 1-year old brown trout exhibited high mortality during in situ bioassays in Krycklan streams during spring flood, with a threshold at pH 4.8-5.4 (Serrano et al., 2008), and 2-year old brown trout showed a similar response to in situ acidity during spring flood in other Swedish streams (Laudon et al., 2005). Thus, although the spring flood episode and associated acidity in many boreal streams occurs concurrently with larval and yolk-sac fry stages, it is age- 0 juveniles experiencing autumn rain-driven episodes, and 1-year old juveniles experiencing their first spring flood that are more likely to be constrained by stream acidity (Serrano et al., 2008).

The fact that brown trout showed a strong preference for streams with low $\mathrm{Al}_{\mathrm{i}}$, in spite of the overall low $\mathrm{Al}_{\mathrm{i}}$ concentrations, is puzzling. Previous studies in naturally acidic 
humic-rich waters have generally not found a correlation between $\mathrm{Al}_{\text {tot }}$ (or $\mathrm{Al}_{\mathrm{i}}$, if measured) and fish response (Lacroix, 1989; Serrano et al., 2008). This lack of correlation has been attributed to the capacity of dissolved organic matter to bind $\mathrm{Al}$ and reduce the negative effects of $\mathrm{Al}$ on the gills (Lacroix, 1989). However, in our study, brown trout showed a preference for streams which maintained very low $\mathrm{Al}_{\mathrm{i}}$ even during spring flood, even though $\mathrm{Al}_{\mathrm{i}}$ concentrations were well below published toxicity thresholds (Fivelstad and Leivestad, 1984; Sadler and Lynam, 1987). One possible explanation for the apparent discrepancy would be if the WHAM model that we used (Tipping, 1994; Cory et al., 2006) underestimated the true proportion of toxic $\mathrm{Al}_{\mathrm{i}}$ in the presence of high dissolved organic matter concentrations. It has been shown that a substantial part of dissolved organic acidity can be in the strong acid form, which would favor fully dissociated $\mathrm{Al}$ binding and enhanced toxicity effects (discussed in Tipping and Carter, 2011; Fakhraei and Driscoll, 2015), and the modeling results are sensitive to this parameter. However, a test of WHAM with humic rich waters from northern Sweden, including from the Krycklan catchment, showed good agreement with lab-speciated $\mathrm{Al}_{\mathrm{i}}$ analyses, placing $89-94 \%$ of the samples into the correct toxicological category (Cory et al., 2007), so we do not expect a substantial bias in the modeled $\mathrm{Al}_{\mathrm{i}}$ values. Additionally, within the stream network, $\mathrm{Al}_{\mathrm{i}}$ co-varies with $\mathrm{pH}$ and other important habitat variables making it difficult to disentangle the discrete effects of $\mathrm{Al}_{\mathrm{i}}$, so the patterns observed should not be interpreted as strict acidity thresholds.

\section{Importance of Local Site Physical Habitat Characteristics}

Brown trout in our study were more strongly associated with variations in local site physical characteristics than with variation in acidity (Table 5; Figure 5). The clearest example of this was the fact that in spite of high $\mathrm{pH}$, brown trout had relatively little presence in the largest, silt-underlain streams, suggesting that they avoided stream reaches underlain by fine substrate. However, instead of utilizing the boulder/gravelly substrate associated with unsorted till, brown trout showed a strong preference for the more consistently sized coarse sorted sediments (gravel-cobble) associated with glaciofluvial deposits (Figure 6). This is likely due to the utility of the coarse sorted glaciofluvial sediments as spawning and nursery habitat. Brown trout prefer substrate in this size range for building redds (Heggenes, 1988b; Armstrong et al., 2003). This association also highlights the connection between stream chemistry and geology, since areas with extensive glaciofluvial deposits tended to also have relatively high $\mathrm{pH}$ and $\mathrm{ANC}$, compared with areas underlain by till. Glaciofluvial deposits can provide areas of seepage inputs of relatively well-buffered groundwater (e.g., Banks et al., 1998), which can in turn provide areas of chemical refugia for brown trout during acid episodes (Carline et al., 1992).

Regardless of the mechanism, the association of brown trout with glaciofluvial deposits highlights the connection between present-day biological assemblages and the legacy of spatial patterns of water flow during the last glacial melt period. Points of intersection between the present-day stream network and the historical glaciofluvial stream network may form nodes of habitat particularly suitable to brown trout. Silty areas, in this case formed from a postglacial delta and thus also a legacy of the last glacial melt, are not generally appropriate salmonid spawning habitat because eggs can be smothered (Soulsby et al., 2001; Lapointe et al., 2004). In experiments with incubation of trout eggs during spring flood at some of the stream sites in this study, high egg mortality was observed only at silty sites, due to siltingover and suffocation (Serrano et al., 2008). The lack of physical cover due to the scarcity of rocks and attached algae in sites which have only fine sediments may also contribute to the apparent avoidance of these sites by trout, as could lack of visibility due to high suspended particulate matter concentrations during high flow.

Brown trout also had a strong positive association with attached filamentous green algae (Figure 6). This suggests that the filamentous algae is either (1) directly or indirectly beneficial to brown trout (2) responding positively to environmental factors which also support brown trout presence. Once established, filamentous green algae are considered unpalatable for benthic invertebrates (Cummins, 1973; Mundie et al., 1991), and are avoided by drifting invertebrates which serve as preferred food for drift-feeders such as brown trout (F. Lepori, pers. comm.). Thus, the filamentous green algae in Krycklan are unlikely to be a significant source of food for brown trout, directly or indirectly. However, filamentous algae could be a direct benefit by serving as physical cover for the fish (e.g., Mäki-Petäys et al., 1997).

The higher densities of brown trout associated with glaciofluvial sediment in Krycklan, and particularly the high densities of age- 0 brown trout in the few $\mathrm{km}$ of stream reach near the large glaciofluvial deposit in the east, suggest that limited dispersal from spawning/natal areas may play an important role in regulating the distribution of brown trout in this catchment. Direct monitoring of within-stream movements of brown trout in Scandinavia and elsewhere have commonly noted minimal dispersal from natal areas, often on the order of a few hundred meters or less (Solomon and Templeton, 1976; Heggenes, 1988a), although movement of several $\mathrm{km}$ by adults is also common as found in a study of Pennsylvania, USA streams (Davis et al., 2015).

\section{Catchment-Scale Vs. Local Site Associations With Brown Trout Distributions}

Our results imply a strong organizing role of catchmentscale landscape characteristics in boreal stream ecosystems, mediated in part by local stream chemistry and physical habitat-supporting the concept of a strong connection between watersheds and in-stream habitat, promoted by Hynes (1975) and expanded upon by Fausch et al. (2002) and many others since (e.g., Kocovsky and Carline, 2006; Johnson and Host, 2010; Alcaraz-Hernandez et al., 2016). This relationship between catchment-scale and local habitat can be envisioned as establishing a hierarchical set of environmental filters (e.g., Poff, 1997; Kennard et al., 2007), all of which must be passed through successfully in order for a given species to thrive at 
a given location. The identity of the filters are likely to differ depending on context and spatial scale under considerationfor example, a large-scale study in northern Spain found that the distribution of brown trout could be modeled using location and catchment variables including distance to sea, elevation, valley floor width, and mean annual flow (Gonzalez-Ferreras et al., 2016), while Frederico et al. (2014) was able to use climatic and geomorphological information to predict local stream chemistry and thereby model fish distributions in the Amazon river basin. In the case of the smaller-scale boreal Krycklan catchment, both acidity and physical habitat (e.g., in-stream cover and distance to nearest in-stream glaciofluvial deposits) appear as proximal site-scale factors playing a role in restricting brown trout distributions.

In our study, catchment characteristics explained more of the variance in fish distributions than did either local site physical or chemistry characteristics. This indicates that it may be possible to predict site suitability for brown trout from available map data. Kocovsky and Carline (2006) reported a similarly strong relationship between landscape-scale predictors and brook trout densities in clear water Pennsylvania, USA streams. Other studies have found a greater importance of local spatial scales, with for instance Hughes et al. (2015) finding in a survey of the western USA that site-scale variables explained slightly more variance in fish assemblages than catchment or large-scale spatial (location) variables. In another large-scale study in New York, USA streams, site suitability modeled from map variables was not able to successfully predict maximum abundance of brown trout (Alexiades and Fisher, 2015), suggesting that other localscale factors or colonization-related factors were more important. Although studies of similar scope to ours have been carried out in other landscapes, our work gives a clear example of this hierarchical relationship at work in a boreal catchment, where the humic waters give rise to a distinctly different water chemistry than that in most past studies relating catchment characteristics to stream water acidity and in turn fish distributions (e.g., Baker and Christensen, 1991; Baldigo and Lawrence, 2001; Kocovsky and Carline, 2005).

Much of the strength of the catchment characteristics-fish association can be explained by the influence of catchment-scale landscape characteristics on stream chemistry and site physical characteristics. Stream water chemistry is directly influenced by catchment hydrology and sediment/soils (e.g., Johnson et al., 1981; Buffam et al., 2008), while local site characteristics are likely to be similar to catchment characteristics, and may also be influenced by catchment-scale geomorphological features and hydrology (e.g., Buffington et al., 2004). Thus it is important to consider catchment-scale processes that structure the physical environment and influence water chemistry when undertaking stream restoration projects. The catchment variables of greatest relevance in our study include the coverage of lakes and coarse sorted (glaciofluvial) sediments. These are relatively minor landscape elements in terms of total areal coverage, but their heterogeneous distribution in the landscape is apparently important in determining fish distributions, likely due to their relevance for local physical habitat-for instance, small lakes in the boreal landscape can help maintain baseflow of connected streams during dry periods (Leach and Laudon, 2019). Other more prevalent landscape elements (till, peat and silty sediments) strongly influence stream water $\mathrm{pH}$ (Buffam et al., 2008) and $\mathrm{Al}_{\mathrm{i}}$ (Cory et al., 2006).

\section{Potential for Future Research Building on This Work}

Although in this study we decided to focus on density or presence/absence of a single species of interest as the response variables, the same type of study can be carried out with a broader focus on fish communities as a multivariate response variable, or using fish biomass or species richness as response variables of interest. These other response variables have been used to good effect in recent studies (e.g., Cheek et al., 2016; Baldigo et al., 2019) and their use in future studies in Krycklan and other boreal catchments could shed further light on the factors controlling boreal fish communities.

Finally, this study represents an attempt at a distributed coverage of an entire stream network at the intermediate scale proposed by Fausch et al. (2002), though logistically we were still limited to discrete stream reaches. In order to explore the mechanisms responsible for the observed correlations, an approach utilizing a more continuous monitoring of the entire riverscape including fish movements through the system, is a key next step. Continuous map-derived landscape-scale data is already available, and can be used with some success to predict variation in chemistry (Buffam et al., 2008; Ågren et al., 2014), but linkages to biota still require a combination of on-the-ground surveys and remote-sensing techniques-excitingly, technologies now available are opening up a new world of possibilities for working within stream networks at multiple spatial scales (e.g., Johnson and Host, 2010; Cheek et al., 2016).

\section{DATA AVAILABILITY STATEMENT}

The raw data supporting the conclusions of this article will be made available by the authors, without undue reservation.

\section{AUTHOR CONTRIBUTIONS}

IB conceived of the study, oversaw field sampling and lab analyses, carried out statistical analyses, wrote the first draft, and led the writing effort. HL and $\mathrm{KB}$ contributed input to the conceptual framework, interpretation, and writing. All authors contributed to the article and approved the submitted version.

\section{FUNDING}

Funding was provided for the research by a grant to HL (2142004-901) from the Swedish Research Council for Environment, Agricultural Sciences and Spatial Planning (FORMAS), and by a grant from the Swedish Environmental Protection Agency. 


\section{ACKNOWLEDGMENTS}

Thanks to researchers and staff at the Vindeln Experimental Forest Research Station for providing logistical support and research infrastructure. The Krycklan catchment project depends on the competent work of many research assistants and students, and their help is gratefully acknowledged. In particular, Ignacio Serrano is thanked for his dedicated work carrying out electrofishing and habitat surveys, and for his intellectual

\section{REFERENCES}

Ågren, A., Buffam I, Jansson, M., and Laudon, H. (2007). Importance of seasonality and small streams for the landscape regulation of dissolved organic carbon export. J. Geophys. Res. 112:G03003, doi: 10.03010.01029/02006JG000381

Ågren, A. M., Buffam, I., Cooper, D. M., Tiwari, T., Evans, C. D., and Laudon, H. (2014). Can the heterogeneity in stream dissolved organic carbon be explained by contributing landscape elements? Biogeosciences 11, 1199-1213. doi: 10.5194/bg-11-1199-2014

Alcaraz-Hernandez, J. D., Munoz-Mas, R., Martinez-Capel, F., Garofano-Gomez, V., and Vezza, P. (2016). Generalized additive models to predict adult and young brown trout (Salmo trutta Linnaeus, 1758) densities in Mediterranean rivers. J. Appl. Ichthyol. 32, 217-228. doi: 10.1111/jai.13025

Alexiades, A. V., and Fisher, W. L. (2015). Broad-scale habitat classification variables predict maximum local abundance for native but not non-native trout in New York streams. Aquat. Conserv. Marine Freshwater Ecosyst. 25, 31-40. doi: $10.1002 /$ aqc. 2476

Andersson, B., and Andersson, P. (1984). The distribution of trout (Salmo trutta L.) in relation to $\mathrm{pH}-$ an inventory of small streams in Delsbo, Central Sweden. Rep. Inst. Freshwater Res. Drottningholm Rep. 61, 28-33.

Armstrong, J. D., Kemp, P. S., Kennedy, G. J. A., Ladle, M., and Milner, N. J. (2003). Habitat requirements of Atlantic salmon and brown trout in rivers and streams. Fish. Res. 62, 143-170. doi: 10.1016/S0165-7836(02)00160-1

Baker, J. P., and Christensen, S. W. (1991). "Effects of acidification on biological communities in aquatic ecosystems," in Acidic Deposition and Aquatic Ecosystems, ed D. F. Charles (New York, NY: Springer-Verlag), 83-106.

Baker, J. P., VanSickle, J., Gagen, C. J., DeWalle, D. R., Sharpe, W. E., Carline, R. F., et al. (1996). Episodic acidification of small streams in the northeastern United States: effects on fish populations. Ecolo. Appl. 6, 422-437. doi: $10.2307 / 2269380$

Baldigo, B. P., George, S. D., Sullivan, T. J., Driscoll, C. T., Burns, D. A., Shao, S., et al. (2019). Probabilistic relations between acid-base chemistry and fish assemblages in streams of the western adirondack mountains, New York, USA. Canad. J. Fisher. Aquat. Sci. 76, 2013-2026. doi: 10.1139/cjfas-2018-0260

Baldigo, B. P., and Lawrence, G. B. (2000). Composition of fish communities in relation to stream acidification and habitat in the Neversink River, New York. Trans. Am. Fisher. Soc. 129, 60-76. doi: 10.1577/1548-8659(2000)129<0060:COFCIR >2.0.CO;2

Baldigo, B. P., and Lawrence, G. B. (2001). Effects of stream acidification and habitat on fish populations of a North American river. Aquat. Sci. 63, 196-222. doi: 10.1007/PL00001352

Banks, D., Midtgard, A. K., Frengstad, B., Krog, J. R., and Strand, T. R. (1998). The chemistry of Norwegian groundwaters: II. the chemistry of 72 groundwaters from quaternary sedimentary aquifers. Sci. Total Environ. 222, 93-105. doi: 10.1016/S0048-9697(98)00292-7

Bishop, K. H., Laudon, H., and Köhler, S. (2000). Separating the natural and anthropogenic components of spring flood $\mathrm{pH}$ decline: a method for areas that are not chronically acidified. Water Resour. Res. 36, 1873-1884. doi: 10.1029/2000WR900030

Bohlin, T., Hamrin, S., Heggberget, T. G., Rasmussen, G., and Saltveit, S. J. (1989). Electrofishing-theory and practice with special emphasis on salmonids. Hydrobiologia 173, 9-43. doi: 10.1007/BF00008596

Brazner, J. C., Tanner, D. K., Detenbeck, N. E., Batterman, S. L., Stark, S. L., Jagger, L. A., et al. (2005). Regional, watershed, and site-specific environmental input which improved the paper, and Marcus Wallin is thanked for collecting the challenging winter stream chemistry samples. Thanks also to Henrik Jensen for coordinating the electrofishing effort, and to Neil Cory for providing WHAM-modeled inorganic aluminum values. Discussions with Göran Englund and Fabio Lepori helped to improve the study, and feedback from Magnus Bergknut, Magdalena Wiedermann, Sonja Keel, Monica Turner, Patrick Kocovsky and two anonymous reviewers helped to refine the paper.

influences on fish assemblage structure and function in western Lake Superior tributaries. Canad. J. Fisher. Aquat. Sci. 62, 1254-1270. doi: 10.1139/ f05-031

Buffam, I. (2007). Linking landscape characteristics, streamwater chemistry, and brown trout (Salmo trutta) distributions in a boreal stream network. Ph.D. Thesis. 2007:33, Swedish University of Agricultural Sciences, Umeå, Sweden.

Buffam, I., Laudon, H., Seibert, J., Mörth, C.-M., and Bishop, K. (2008). Spatial heterogeneity of the spring flood acid pulse in a boreal stream network. Sci. Total Environ. 407, 708-722. doi: 10.1016/j.scitotenv.2008.10.006

Buffam, I., Laudon, H., Temnerud, J., Mörth, C.-M., and Bishop, K. (2007). Landscape-scale variability of acidity and dissolved organic carbon during spring flood in a boreal stream network. J. Geophys. Res. 112:G01022, doi: 10.1010.01029/02006JG000218

Buffington, J. M., Montgomery, D. R., and Greenberg, H. M. (2004). Basin-scale availability of salmonid spawning gravel as influenced by channel type and hydraulic roughness in mountain catchments. Canad. J. Fisher. Aquat. Sci. 61, 2085-2096. doi: 10.1139/f04-141

Carline, R. F., Dewalle, D. R., Sharpe, W. E., Dempsey, B. A., Gagen, C. J., and Swistock, B. (1992). Water chemistry and fish community responses to episodic stream acidification in Pennsylvania, USA. Environ. Pollut. 78, 45-48. doi: 10.1016/0269-7491(92)90008-X

Cheek, B. D., Grabowski, T. B., Bean, P. T., Groeschel, J. R., and Magnelia, S. J. (2016). Evaluating habitat associations of a fish assemblage at multiple spatial scales in a minimally disturbed stream using low-cost remote sensing. Aquat. Conserv. Marine Freshwat. Ecosyst. 26, 20-34. doi: 10.1002/aqc.2569

Cory, N., Andren, C. M., and Bishop, K. (2007). Modelling inorganic aluminium with WHAM in environmental monitoring. Appl. Geochem. 22, 1196-1201. doi: 10.1016/j.apgeochem.2007.03.011

Cory, N., Buffam, I., Laudon, H., Köhler, S., and Bishop, K. (2006). Landscape control of stream water aluminum in a boreal catchment during spring flood. Environ. Sci. Technol. 40, 3494-3500. doi: 10.1021/es0523183

Cory, N. D. (2006). Natural and Anthropogenic Influences on Aluminium in the Humic Rich Waters of Northern Sweden, No. 2006:63. Doctoral. Ph.dissertation D, Swedish University of Agricultural Sciences, Uppsala, Sweden.

Cummins, K. W. (1973). Trophic relations of aquatic insects. Annu. Rev. Entomol. 18, 183-206. doi: 10.1146/annurev.en.18.010173.001151

Davis, L. A., Wagner, T., and Bartron, M. L. (2015). Spatial and temporal movement dynamics of brook Salvelinus fontinalis and brown trout Salmo trutta. Environ. Biol. Fishes 98, 2049-2065. doi: 10.1007/s10641-015-0428-y

Degerman, E., and Lingdell, P. E. (1993). pHisces-fisk som indikator på lågt pH (In Swedish). Inform. från Sötvattenslaboratoriet, Drottningholm 3, 37-54.

Degerman, E., and Sers, B. (1999). Elfiske. Standardiserat elfiske och praktiska tips med betoning på säkerhet såväl för fisk som fiskare (In Swedish). Fiskeriverket information 1999: 3.

Dieterman, D. J., and Hoxmeier, R. J. H. (2011). Demography of juvenile and adult brown trout in streams of Southeastern Minnesota. Trans. Am. Fish. Soc. 140, 1642-1656. doi: 10.1080/00028487.2011.641883

Erlandsson, M., Cory, N., Folster, J., Kohler, S., Laudon, H., Weyhenmeyer, G. A., et al. (2011). Increasing dissolved organic carbon redefines the extent of surface water acidification and helps resolve a classic controversy. Bioscience 61, 614-618. doi: 10.1525/bio.2011.61.8.7

Fakhraei, H., and Driscoll, C. T. (2015). Proton and aluminum binding properties of organic acids in surface waters of the Northeastern US. Environ. Sci. Technol. 49, 2939-2947. doi: 10.1021/es504024u 
Fausch, K. D., Torgersen, C. E., Baxter, C. V., and Li, H. W. (2002). Landscapes to riverscapes: bridging the gap between research and conservation of stream fishes. Bioscience 52, 483-498. doi: 10.1641/00063568(2002)052[0483:LTRBTG]2.0.CO;2

Fausch, K. D., and White, R. J. (1981). Competition between brook trout (Salvelinus fontinalis) and brown trout (Salmo trutta) for positions in a Michigan stream. Canad. J. Fisher. Aquat. Sci. 38, 1220-1227. doi: 10.1139/f81-164

Fivelstad, S., and Leivestad, H. (1984). Aluminium toxicity to Atlantic salmon (Salmo salar L.) and brown trout (Salmo trutta L.): Mortality and physiological response. Rep. Inst. Freshwater Res. Drottningholm Rep. 61, 69-77.

Frederico, R. G., De Marco, P., and Zuanon, J. (2014). Evaluating the use of macroscale variables as proxies for local aquatic variables and to model stream fish distributions. Freshw. Biol. 59, 2303-2314. doi: 10.1111/fwb.12432

Gonzalez-Ferreras, A. M., Barquin, J., and Penas, F. J. (2016). Integration of habitat models to predict fish distributions in several watersheds of Northern Spain. J. Appl. Ichthyol. 32, 204-216. doi: 10.1111/jai.13024

Harpold, A. A., Burns, D. A., Walter, M. T., and Steenhuis, T. S. (2013). Hydrogeomorphology explains acidification-driven variation in aquatic biological communities in the Neversink Basin, USA. Ecol. Appl. 23, 791-800. doi: 10.1890/12-0603.1

Heggenes, J. (1988a). Effect of experimentally increased intraspecific competition on sedentary adult brown trout (Salmo trutta) movement and stream habitat choice. Canad. J. Fisher. Aquatic. Sci. 45, 1163-1172. doi: 10.1139/f88-139

Heggenes, J. (1988b). Substrate preferences of brown trout fry (Salmo trutta) in artificial stream channels. Canad. J. Fisher. Aquatic. Sci. 45, 1801-1806. doi: $10.1139 /$ f $88-211$

Hemond, H. F. (1990). Acid neutralizing capacity, alkalinity, and acid-base status of natural-waters containing organic-acids. Environ. Sci. Technol. 24, 1486-1489. doi: 10.1021/es00080a005

Herlihy, A. T., Sifneos, J. C., Hughes, R. M., Peck, D. V., and Mitchell, R. M. (2020). The relation of lotic fish and benthic macroinvertebrate condition indices to environmental factors across the conterminous USA. Ecol. Indic. 112:10598. doi: 10.1016/j.ecolind.2019.105958

Hesthagen, T., and Heggenes, J. (2003). Competitive habitat displacement of brown trout by Siberian sculpin: the role of size and density. J. Fish Biol. 62, 222-236. doi: 10.1046/j.1095-8649.2003.00024.x

Hesthagen, T., Heggenes, J., Larsen, B. M., Berger, H. M., and Forseth, T. (1999). Effects of water chemistry and habitat on the density of young brown trout Salmo trutta in acidic streams. Water Air Soil Pollut. 112, 85-106. doi: 10.1023/A:1005068404832

Hruška, J., Köhler, S., Laudon, H., and Bishop, K. (2003). Is a universal model of organic acidity possible: comparison of the acid/base properties of dissolved organic carbon in the boreal and temperate zones. Environ. Sci. Technol. 37, 1726-1730. doi: 10.1021/es0201552

Hughes, R. M., Herlihy, A. T., and Sifneos, J. C. (2015). Predicting aquatic vertebrate assemblages from environmental variables at three multistate geographic extents of the western USA. Ecol. Indic. 57, 546-556. doi: 10.1016/j.ecolind.2015.04.044

Hynes, H. B. N. (1975). The stream and its valley. Verhandlungen Internationale Vereinigung fur Theoretische und Angewandte Limnologie 19, 1-15. doi: 10.1080/03680770.1974.11896033

Ikuta, K., Munakata, A., Aida, K., Amano, M., and Kitamura, S. (2001). Effects of low $\mathrm{pH}$ on upstream migratory behavior in land-locked sockeye salmon Oncorhynchus nerka. Water Air Soil Pollut. 130, 99-106. doi: 10.1023/A:1012299402450

Ivarsson, H., and Johnsson, T. (1988). Stratigraphy of the Quaternary deposits in the Nyänges drainage area, within the Svartbergets forest experimental area and a general geomorphological description of the Vindeln region. Umeå: Svartbergets and Kulbäckslidens research parks.

Jackson, D. A., Peres-Neto, P. R., and Olden, J. D. (2001). What controls who is where in freshwater fish communities - the roles of biotic, abiotic, spatial factors. Canad. J. Fisher. Aquat. Sci. 58, 157-170. doi: 10.1139/cjfas58-1-157

Johnson, L. B., and Host, G. E. (2010). Recent developments in landscape approaches for the study of aquatic ecosystems. J. North Am. Benthol. Soc. 29, 41-66. doi: 10.1899/09-030.1
Johnson, N. M., Driscoll, C. T., Eaton, J. S., Likens, G. E., and McDowell, W. H. (1981). Acid rain, dissolved aluminium and chemical weathering at the Hubbard Brook experimental forest, New Hampshire. Geochimica et cosmochimica acta 1421-1437. doi: 10.1016/0016-7037(81)9 0276-3

Jutila, E., Ahvonen, A., and Laamanen, M. (1999). Influence of environmental factors on the density and biomass of stocked brown trout, Salmo trutta L., parr in brooks affected by intensive forestry. Fish. Manag. Ecol. 6, 195-205. doi: 10.1046/j.1365-2400.1999.00149.x

Kennard, M. J., Olden, J. D., Arthington, A. H., Pusey, B. J., and Poff, N. L. (2007). Multiscale effects of flow regime and habitat and their interaction on fish assemblage structure in eastern Australia. Canad. J. Fisher. Aquat. Sci. 64, 1346-1359. doi: 10.1139/f07-108

Kocovsky, P. M., and Carline, R. F. (2005). Stream pH as an abiotic gradient influencing distributions of trout in Pennsylvania streams. Trans. Am. Fish. Soc. 134, 1299-1312. doi: 10.1577/T04-177.1

Kocovsky, P. M., and Carline, R. F. (2006). Influence of landscape-scale factors in limiting brook trout populations in Pennsylvania streams. Trans. Am. Fish. Soc. 135, 76-88. doi: 10.1577/T04-175.1

Korsu, K., Huusko, A., and Muotka, T. (2007). Niche characteristics explain the reciprocal invasion success of stream salmonids in different continents. Proc. Natl. Acad. Sci. USA. 104, 9725-9729. doi: 10.1073/pnas.0610719104

Lacroix, G. L. (1989). Ecological and physiological responses of Atlantic salmon in acidic organic rivers of Nova Scotia, Canada. Water Air Soil Pollut. 46, 375-386. doi: 10.1139/f89-250

Lapointe, M., Bergeron, N., Berube, F., Pouliot, M., and Johnston, P. (2004). Interactive effects of substrate sand and silt contents, redd-scale hydraulic gradients, and interstitial velocities on egg-to-emergence survival of Atlantic salmon (Salmo salar). Canad. J. Fisher. Aquat. Sci. 61, 2271-2277. doi: 10.1139/f04-236

Laudon, H., and Bishop, K. (2002). Episodic stream water decline during autumn storms following a summer drought. Hydrol. Process. 16, 1725-1733. doi: 10.1002/hyp.360

Laudon, H., and Buffam, I. (2008). Impact of changing DOC concentrations on the potential distribution of acid sensitive biota in a boreal stream network. Hydrol. Earth Syst. Sci. 12, 425-435. doi: 10.5194/hess-12-425-2008

Laudon, H., Poléo, A. B. S., Vollestad, L. A., and Bishop, K. (2005). Survival of brown trout during spring flood in DOC-rich streams in northern Sweden: the effect of present acid deposition and modelled pre-industrial water quality. Environ. Pollut. 135, 121-130. doi: 10.1016/j.envpol.2004.09.023

Laudon, H., Sponseller, R. A., and Bishop, K. (2021). From legacy effects of acid deposition in boreal streams to future environmental threats. Environ. Res. Lett. 16:64. doi: 10.1088/1748-9326/abd064

Laudon, H., Taberman, I., Ågren, A., Futter, M., Ottosson-Lofvenius, M., and Bishop, K. (2013). The Krycklan Catchment Study-A flagship infrastructure for hydrology, biogeochemistry, and climate research in the boreal landscape. Water Resour. Res. 49, 7154-7158. doi: 10.1002/wrcr.20520

Laudon, H., Westling, O., and Bishop, K. (2000). Cause of pH decline in stream water during spring melt runoff in northern Sweden. Canad. J. Fisher. Aquat. Sci. 57, 1888-1900. doi: 10.1139/f00-131

Leach, J. A., and Laudon, H. (2019). Headwater lakes and their influence on downstream discharge. Limnol. Oceanograph. Lett. 4, 105-112. doi: $10.1002 /$ lol2.10110

Likens, G. E., and Buso, D. C. (2006). Variation in streamwater chemistry throughout the Hubbard Brook Valley. Biogeochemistry 78, 1-30. doi: 10.1007/s10533-005-2024-2

Mäki-Petäys, A., Muotka, T., Huusko, A., Tikkanen, P., and Kreivi, P. (1997). Seasonal changes in habitat use and preference by juvenile brown trout, Salmo trutta, in a northern boreal river. Canad. J. Fisher. Aquat. Sci. 54, 520-530. doi: 10.1139/f96-311

Montgomery, D. R., Beamer, E. M., Pess, G. R., and Quinn, T. P. (1999). Channel type and salmonid spawning distribution and abundance. Canad. J. Fisher. Aquat. Sci. 56, 377-387. doi: 10.1139/f98-181

Moran, P. A. P. (1951). A mathematical theory of animal trapping. Biometrica 38, 307-311. doi: 10.1093/biomet/38.3-4.307

Mundie, J. H., Simpson, K. S., and Perrin, C. J. (1991). Responses of stream periphyton and benthic insects to increases in dissolved inorganic 
phosphorus in a mesocosm. Canad. J. Fisher. Aquat. Sci. 48, 2061-2072. doi: 10.1139/f91-245

Mylona, S. (1996). Sulphur dioxide emissions in Europe 1880-1991 and their effect on sulphur concentrations and depositions. Tellus Series B-Chem. Physic. Meteorol. 48, 662-689. doi: 10.3402/tellusb.v48i5.15939

Öhlund, G., Nordwall F, Degerman, E., and Eriksson, T. (2008). Life history and large-scale habitat use of brown trout (Salmo trutta) and brook trout (Salvelinus fontinalis)_implications for species replacement patterns. Canad. J. Fisher. Aquat. Sci. 65, 633-644. doi: 10.1139/f08-003

Økland, R. H., and Eilertsen, O. (1994). Canonical correspondence analysis with variance partitioning: some comments and an application. J. Vegetation Sci. 5, 117-126. doi: $10.2307 / 3235645$

Olden, J. D., Kennard, M. J., Leprieur, F., Tedesco, P. A., Winemiller, K. O., and Garcia-Berthou, E. (2010). Conservation biogeography of freshwater fishes: recent progress and future challenges. Diver. Distribut. 16, 496-513. doi: 10.1111/j.1472-4642.2010.00655.x

Oliveira, J. M., Segurado, P., Santos, J. M., Teixeira, A., Ferreira, M. T., and Cortes, R. V. (2012). Modelling stream-fish functional traits in reference conditions: regional and local environmental correlates. PLos ONE 7:787. doi: 10.1371/journal.pone.0045787

Ottosson Löfvenius, M., Kluge, M., and Lundmark, T. (2003). Snow and soil frost depth in two types of shelterwood and a clear-cut area. Scand. J. For. Res. 18, 54-63. doi: 10.1080/0891060310002345

Poff, N. L. (1997). Landscape filters and species traits: Towards mechanistic understanding and prediction in stream ecology. J. North Am. Benthol. Soc. 16, 391-409. doi: 10.2307/1468026

Reader, J. P., Dalziel, T. R. K., Morris, R., Sayer, M. D. J., and Dempsey, C. H. (1991). Episodic exposure to acid and aluminium in soft water: survival and recovery of brown trout, Salmo trutta L. J. Fish Biol. 39, 181-196. doi: 10.1111/j.1095-8649.1991.tb04355.x

Reese, H., Nilsson, M., Pahlen, T. G., Hagner, O., Joyce, S., Tingelof, U., et al. (2003). Countrywide estimates of forest variables using satellite data and field data from the national forest inventory. Ambio 32, 542-548. doi: 10.1579/0044-7447-32.8.542

Sadler, K., and Lynam, S. (1987). Some effects on the growth of brown trout from exposure to aluminum at different pH levels. J. Fish Biol. 31, 209-219. doi: 10.1111/j.1095-8649.1987.tb05226.x

Seber, G. A. F. (1982). The Estimation of Animal Abundance and Related Parameters, 2nd ed. C. Griffin, London.

Serrano, I., Buffam, I., Palm, D., Brännäs, E., and Laudon, H. (2008). Thresholds for survival of brown trout during the spring flood acid pulse in streams high in dissolved organic carbon. Trans. Am. Fish. Soc. 137, 1363-1377. doi: $10.1577 /$ T07-069.1

Solomon, D. J., and Templeton, R. G. (1976). Movements of brown trout Salmo trutta L. in a chalk stream. J. Fish Biol. 9, 411-423. doi: 10.1111/j.1095-8649.1976.tb04690.x

Soulsby, C., Youngson, A. F., Moir, H. J., and Malcolm, I. A. (2001). Fine sediment influence on salmonid spawning habitat in a lowland agricultural stream: a preliminary assessment. Sci. Total Environ. 265, 295-307. doi: 10.1016/S0048-9697(00)00672-0

Spens, J., and Ball, J. P. (2008). Salmonid or nonsalmonid lakes: predicting the fate of northern boreal fish communities with hierarchical filters relating to a keystone piscivore. Canad. J. Fisher. Aquat. Sci. 65, 1945-1955. doi: 10.1139/F08-103

Strayer, D. L., Beighley, R. E., Thompson, L. C., Brooks, S., Nilsson, C., Pinay, G., et al. (2003). Effects of land cover on stream ecosystems: roles of empirical models and scaling issues. Ecosystems 6, 407-423. doi: 10.1007/PL000 21506

Tamm, O., and Malmström, C. (1926). The Experimental Forests of Kulbäcksliden and Svartberget in North Sweden. Stockholm: Swedish Institute for Experimental Forestry.

Tipping, E. (1994). Wham-a chemical-equilibrium model and computer code for waters, sediments, and soils incorporating a discrete site electrostatic model of ion-binding by humic substances. Comput. Geosci. 20, 973-1023. doi: 10.1016/0098-3004(94)90038-8

Tipping, E., and Carter, H. T. (2011). Aluminium speciation in streams and lakes of the UK Acid Waters Monitoring Network, modelled with WHAM. Sci. Total Environ. 409, 1550-1558. doi: 10.1016/j.scitotenv.2010.12.030

Tiwari, T., Buffam, I., Sponseller, R. A., and Laudon, H. (2017). Inferring scale-dependent processes influencing stream water biogeochemistry from headwater to sea. Limnol. Oceanogr. 62, S58-S70. doi: 10.1002/lno. 10738

Townsend, C. R., Doledec, S., Norris, R., Peacock, K., and Arbuckle, C. (2003). The influence of scale and geography on relationships between stream community composition and landscape variables: description and prediction. Freshw. Biol. 48, 768-785. doi: 10.1046/j.1365-2427.2003.01043.x

Vanoffelen, H. K., Krueger, C. C., Schofield, C. L., and Keleher, C. (1994). Survival, distribution, and ion composition in 2 strains of brook trout (Salvelinus fontinalis) fry after exposure to episodic $\mathrm{pH}$ depressions in an Adirondack lake. Canad. J. Fisher. Aquat. Sci. 51, 792-799. doi: 10.1139/f94-077

Vincent, R. E., and Miller, W. H. (1969). Altitudinal distribution of brown trout and other fishes in a headwater tributary of the South Platte River, Colorado. Ecology 50, 464-466. doi: 10.2307/1933899

Zippin, C. (1956). An evaluation of the removal method of estimating animal populations. Biometrics 12, 163-189. doi: 10.2307/3001759

Conflict of Interest: The authors declare that the research was conducted in the absence of any commercial or financial relationships that could be construed as a potential conflict of interest.

Publisher's Note: All claims expressed in this article are solely those of the authors and do not necessarily represent those of their affiliated organizations, or those of the publisher, the editors and the reviewers. Any product that may be evaluated in this article, or claim that may be made by its manufacturer, is not guaranteed or endorsed by the publisher.

Copyright (c) 2021 Buffam, Bishop and Laudon. This is an open-access article distributed under the terms of the Creative Commons Attribution License (CC BY). The use, distribution or reproduction in other forums is permitted, provided the original author(s) and the copyright owner(s) are credited and that the original publication in this journal is cited, in accordance with accepted academic practice. No use, distribution or reproduction is permitted which does not comply with these terms. 